\title{
A synopsis of the African genus Whitfieldia (Acanthaceae: Whitfieldieae) and a key to the species
}

\author{
Aurélie Grall $^{1}$ (1) \& lain Darbyshire ${ }^{1}$
}

Summary. We present a synopsis and an identification key for the 13 species and one subspecies of the African genus Whitfieldia Hook. (Acanthaceae: Acanthoideae: Whitfieldieae). This work is based on the observation and analysis of morphological data from herbarium specimens and photographs of Whitfieldia species, and the study of all the relevant literature on the genus. Whitfieldia latiflos C.B.Clarke ex Stapf from Liberia is reinstated as an accepted species and a full description and illustration are provided. A new subspecies, W. colorata C.B.Clarke ex Stapf subsp. tigrina A.Grall \& I.Darbysh., also from Liberia, is described. In addition, W. arnoldiana De Wild. \& T.Durand and W. letestui Benoist are treated as synonyms of W. laurentii (Lindau) C.B.Clarke and W. preussii (Lindau) C.B.Clarke respectively for the first time. Eleven names in Whitfieldia are lectotypified. Reference specimens, relevant literature, habitat notes, distribution maps, taxonomic notes and a preliminary assessment of the conservation status and extinction risk are provided for each taxon. Four species are considered to be threatened of which two ( W. latiflos and W. rutilans Heine) are assessed as Endangered (EN) while two others (W. purpurata (Benoist) Heine and W. thollonii (Baill.) Benoist) are placed in the Vulnerable (VU) category. In addition, two taxa are assessed as Near Threatened (NT) and one is currently considered to be Data Deficient (DD).

Key Words. Africa, conservation, East African forests, Guineo-Congolian forests, systematics, taxonomy.

\section{Introduction}

Wild plants belonging to the genus Whitfieldia Hook. (Hooker 1845: t.4155) (Acanthaceae: Acanthoideae: Whitfieldieae) grow in the forests of tropical continental Africa from Guinea in the west to Ethiopia in the east, and south to Angola, Zambia and Mozambique, with highest diversity in the Guineo-Congolian phytogeographical region (Vollesen 2008). The genus is perhaps best known for the striking large whiteflowered species W. elongata (P.Beauv.) De Wild. \& T.Durand ("white candles"), which is widely cultivated and has a range of uses from medicine to extraction of dye (Burkill 1985), but many of the species are highly attractive and have horticultural potential. Current literature and taxonomic databases record 12 (Vollesen 2008 \& 2013; Burrows et al. 2018) to 14 accepted species of Whitfieldia (African Plants Database 2020; POWO 2020).

\section{The tribe Whitfieldieae}

Based on combined morphological analyses and DNA sequence data, Manktelow et al. (2001) recognised the tribe Whitfieldieae of the Acanthaceae to accommodate Whitfieldia together with two Afro-Malagasy genera, Chlamydacanthus Lindau and Lankesteria Lindl. Subsequent molecular phylogenetic studies have added the Malagasy endemic genera Camarotea Scott Elliot, Forcipella Baill., Leandriella Benoist and Zygoruellia Baill. to this tribe (McDade et al. 2008; Tripp et al. 2013). McDade et al. (2008) recognised a core Whitfieldieae clade, comprising Whitfieldia, Chlamydacanthus, Camarotea, Forcipella and Leandriella, which are monophyletic with strong support. They found Lankesteria to be only weakly supported as a basal member of Whitfieldieae s.l.

Manktelow et al. (2001) proposed several synapomophies for Whitfieldieae s.l., notably (1) presence of concentric rings of ridges protruding from the testa of the seeds, and (2) pollen with a densely granular circular area surrounding the pores. Most members of core Whitfieldieae (where known) have biporate pollen grains (Manktelow et al. 2001; McDade et al. 2008), circular in apertural view and with a pronounced marginal girdle, which is very similar to the gürtelpollen of Justicieae: Isoglossinae (Kiel et al. 2006; Darbyshire 2009), although this similarity is homoplastic (McDade et al. 2008). Whitfieldia elongata is the only species of that genus with pantoporate pollen (Manktelow et al. 2001) which was otherwise reported in only one other species of Acanthaceae: Megaskepasma erythrochlamys by Prieu et al. (2017). However, Megaskepasma's pollen has

Accepted for publication 7 January 2021. Published online 10 June 2021

1 Herbarium, Royal Botanic Gardens, Kew, Richmond, Surrey, TW9 3AE, UK. e-mail: A.grall@kew.org 
equatorial apertures only (Kiel et al. 2018) and several other genera among Acanthaceae, such as Louteridium and Brunoniella, do also have pantoporate pollen as defined by Prieu et al. 2017 (Tripp et al. 2013). Other useful traits for the identification of core Whitfieldieae include left-contort corolla aestivation (Manktelow et al. 2001 also record imbricate aestivation in Whitfieldieae but this has not so far been observed by the current authors); an androecium of four stamens or very rarely two stamens and two staminodes with no filament curtain for all species (Manktelow et al. 2001; Tripp et al. 2013); and each floral or cymose unit being subtended by paired bracts (or bracteoles). These bracts are usually conspicuous and clasping or partially connate and often partially or entirely enclose the calyces. Based on these morphological traits, a further Malagasy genus - Vindasia Benoist is here included within Whitfieldieae for the first time. Core Whitfieldieae therefore contains 7 genera and \pm 26 species, with a further 7 species in Lankesteria. Generic delimitation is problematic within the Whitfieldieae, the endemic Malagasy genera being particularly poorly differentiated morphologically (I. Darbyshire, pers. obs.).

Within the wider classification of Acanthaceae, McDade et al. (2008) resolved Whitfieldieae as sister to (Andrographideae + Barlerieae) within their "BAWN" clade (i.e. the three tribes Barlerieae, Andrographideae and Whitfieldieae, plus the genus Neuracanthus Nees), but noted that this relationship is only weakly supported. This part of the Acanthaceae is in urgent need of phylogenetic studies to resolve relationships within and between the four major lineages (McDade et al. 2008; Darbyshire et al. 2019).

\section{The genus Whitfieldia Hook.}

Whitfieldia itself is readily identified by having the combination of well-developed racemes, spikes or panicles; each cymose unit being pedunculate and single-flowered; and the calyces being large and showy, exceeding $9 \mathrm{~mm}$ in length. The calyces usually extend beyond or are subequal in length to the bracteoles and are often of a similar colour tone to the corolla, although they can also be green. Chlamydacanthus can also have racemose inflorescences but in that genus the cymose units are often 2 - 3-flowered and the calyces are small (up to $8 \mathrm{~mm}$ long but usually shorter) and hidden within the bracteoles and are not similar in colour to the corolla. The other genera of core Whitfieldieae have fasciculate, glomerulate or shortly umbellate inflorescences.

On a molecular level, studies by Mankletow et al. (2001) and McDade et al. (2008) included only two species of Whitfieldia (W. elongata and W. "stuhlmanni", the latter almost certainly referring to $W$. orientalis Vollesen considering the geographic location [east of the Usambara Mountains, west of Kwani Forest reserve] of the specimen sampled, Iversen et al. 87520, n.v.). Both of the species sequenced were of East African origin. Further molecular work, with the addition of species from west and central Africa (where, based on the current work, c. $70 \%$ of the species are found) is needed to test the monophyly of the genus and biogeographical hypotheses regarding its diversification in Africa. This work is currently underway at Kew, using targeted sequencing of nuclear genes from herbarium specimens, as detailed in Brewer et al. (2019).

\section{Aims of the present study}

Several regional taxonomic treatments of Whitfieldia are available, including for central Africa (Heine 1966; Evrard \& Demillecamps 1992), eastern Africa (Vollesen 2004, 2008) and southern tropical Africa (Vollesen 2013). However, there is no modern global treatment of the genus. In particular, western African species occurring from Guinea to Cameroon are missing from all these recent regional studies and their identification remains problematic. Apart from W. elongata which can tolerate disturbed habitats, most species of Whitfieldia can be indicators of good quality forests (I. Darbyshire, pers. obs.), and several species are range-restricted, hence they are of significant conservation concern. To help identify and protect the species that are most at risk, a comprehensive taxonomic treatment, including identification tools and information on the distribution and ecology is needed.

So the present work aims to provide an identification key to species within the genus and a synoptic account of the recognised taxa, including distribution maps, notes on habitat requirements, citation of voucher specimens and, where available, illustrations to help in the identification of this fascinating group.

\section{Material and Methods}

\section{Material studied and cited}

This study is based primarily on the examination of herbarium specimens held at $\mathrm{BM}, \mathrm{BR}, \mathrm{K}, \mathrm{P}$ and PRE, together with additional material digitised at BRLU, G, LISC, MO and WAG, now transferred to L (herbarium codes follow Thiers, continuously updated). For the more common species (Whitfieldia elongata, W. lateritia Hook., W. laurentii (Lindau) C.B.Clarke), we cite a selection of specimens for each country where the species is found. For all other species, all specimens seen are cited. For most collections, at least one duplicate has been seen by the authors, indicated by an exclamation mark "!". When only a photograph has been seen, the herbarium code is followed by an asterisk “*”. When only a field photograph of the 
collection has been seen by the authors, the collector and collection number are followed by two asterisks “**”. Unseen specimens are only included where the authors have reasonable confidence that the identification is correct. An indication of the phenology ("fl." or "fr.", respectively for flowering or fruiting) has been added before the collection date to aid future phenological studies or targeted collection efforts.

Photographs of species of Whitfieldia in the field, most of them communicated by authors which are listed in the acknowledgements section, but also from Hawthorne \& Jongkind (2006) and Burrows et al. (2018), were studied where available to assist in the comparison of floral morphology and colour.

\section{Measurements and terms employed}

Measurements were made from dry material except for floral dissections, which were made following soaking in Aerosol OT 10\% solution. The morphological terms used to describe the species follow Beentje (2016). The palynological terminology follows Manktelow et al. (2001) and McDade et al. (2008).

\section{Typification}

Wherever required and possible, accepted names and synonyms are lectotypified from amongst the original material.

\section{Distribution Mapping}

For most species, geographic coordinates were determined from specimen labels. Localities have been georeferenced wherever possible, primarily using online and published gazetteers (notably Fuzzy Gazetteer: http://dma.jrc.it/services/gazetteer/) and Google Earth $^{\mathrm{TM}}$.

In some cases where species are more widely distributed in Africa and the number of specimens is too large to be manually georeferenced (Whitfieldia lateritia, W. elongata), data were first imported into GeoCAT (www.geocat.kew.org; Bachman et al. 2011) from GBIF (https://www.gbif.org) and herbarium specimens were then consulted to add missing points and allow a calculation of global extent of occurrence (EOO). In such cases, potentially anomalous points from GBIF were checked before acceptance. For most species, all coordinates were imported into SimpleMappr (Shorthouse 2010) to produce the distribution maps. For $W$. elongata, a polygon was drawn from the GBIF data and imported into QGIS version 2.14.4 (QGIS Team 2020).

\section{Species Conservation (Extinction Risk) Assessments}

The provisional conservation assessments presented here follow the categories and criteria of IUCN (2012). The term 'location' defines a geographically or ecologically distinct area in which a single threat- ening event can rapidly affect all individuals of the taxon present (IUCN 2012). Extent of Occurrence (EOO) was calculated using the GeoCAT tool. Area of Occupancy (AOO) is not used except in specific circumstances where we are confident that we have a good understanding of the number and distribution of localities for a species.

\section{Taxonomic Treatment}

Whitfieldia Hook. (Hooker 1845: t.4155); Nees (1847: 220); Clarke (1899: 65); Heine (1963: 398; 1966: 32); Evrard \& Demillecamps (1992: 89); Vollesen (2008: 266, 2013:173). Type species: Whitfieldia lateritia Hook. Stylarthropus Baill. (Baillon 1890a: 437; 1890b: 822).

Type species: Stylarthropus brazzae Baill.

Leiophaca Lindau (1911: 307). Type species: Leiophaca purpurea Lindau

Pounguia Benoist (1938: 679). Type species: Pounguia purpurata Benoist

Erect or clambering perennial herbs and shrubs. Leaves opposite-decussate, plants evergreen. Cystoliths present, although not always clearly visible on dry material. Inflorescences racemose or paniculate thyrses, terminal or axillary; bracts along inflorescence axis sometimes large but mostly very reduced and/or caducous; bracteoles conspicuous, paired, clasping the base of the flower. Calyx divided into 5 subequal calyx lobes, in most species longer than the bracteoles and clearly visible at anthesis; bracteoles and calyx lobes green or similar in colour to the corolla. Corolla tube campanulate to funnel-shaped with a short to long basal cylindrical portion; limb with 5 lobes, sometimes markedly bilabiate, with 2 upper lobes and 3 lower lobes. Stamens 4, included or exserted from the corolla mouth, subequal or didynamous; filament curtain absent; anthers bithecous, thecae held at an equal height, without appendages. Pollen biporate in all species where data are available except in $W$. elongata where pantoporate (note: pollen morphology is currently unknown for $W$. purpurata only). Ovary 2-locular, with 2 ovules per locule. Capsule stipitate, 2 - 4 seeded; seeds discoid, surfaces with concentric ridges.

DISTRIBUTION. Whitfieldia is native to tropical continental Africa only. It occurs in (from east to west, and north to south) Sierra Leone, Guinea, Liberia, Ivory Coast, Benin, Nigeria, Cameroon, Equatorial Guinea, Gabon, Congo Republic, Central African Republic, Democratic Republic of the Congo (D. R. Congo), South Sudan, Ethiopia, Uganda, Kenya, Tanzania, Rwanda, Angola, Zambia and Mozambique.

Whitfieldia elongata is the only species found within the Dahomey gap (Maesen 6822 in WAG was collected in Dangbo Forest), the region that separates the phytogeographical regions of Upper Guinea from 
Lower Guinea (Salzmann \& Hoelzmann 2005). This appears to be an ecological barrier for species within the genus, which are otherwise recorded on one side or the other of the gap.

\section{Key to species of Whitfieldia}

1. Proximal, unexpanded portion of corolla tube long and narrowly cylindrical, $3.5-5 \mathrm{~cm}$ long, corolla pure

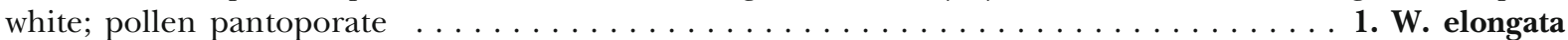
Proximal, unexpanded portion of corolla tube rather broad and short, or if narrowly cylindrical then not exceeding $2.2 \mathrm{~cm}$ long, corolla variously coloured, rarely pure white; pollen (where known) flattened,

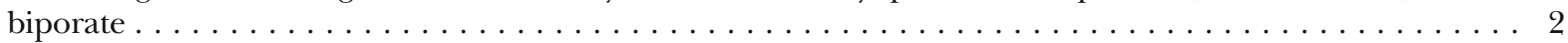

2. Corolla tube white, either both lips or only the lower lip abruptly dark purple (not striped) . . . . . . 3 Corolla without the combination of a white tube and abruptly dark purple lip(s) (if this colour combination exists, the corolla lobes are striped, and the transition is not so abrupt $\ldots \ldots \ldots \ldots$

3. Young branches with floccose stellate hairs; cylindrical portion of corolla tube $0.9-1.2 \mathrm{~cm}$ long . . . 2. W. orientalis Young branches finely puberulous with simple hairs; cylindrical portion of corolla tube $1.4-1.8 \mathrm{~cm}$ long 3. W. stuhlmannii

4. Bracteoles and calyx lobes both subulate, c. $1.5 \mathrm{~mm}$ wide; flowers white with dark purple stripes on the distal

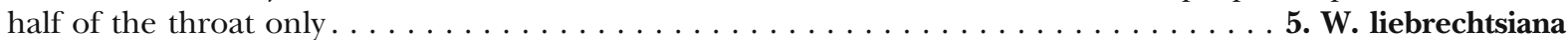
Bracteoles and calyx lobes not subulate simultaneously; if corolla with dark stripes, then these present throughout . 5

5. Proximal, unexpanded portion of corolla tube short, less than or equal to $4.5 \mathrm{~mm} \operatorname{long} \ldots \ldots \ldots$ Proximal, unexpanded portion of corolla tube more than $4.5 \mathrm{~mm}$ long $\ldots \ldots \ldots$

6. Distal portion of corolla tube markedly saccate, with a bend of c. 90 degrees above the short proximal portion of the tube, limb weakly 2-lipped, upper lobes fused for less than half their length and held horizontal, lower lobes slightly reflexed but not markedly deflexed; inflorescence unilateral . . . . . . . . . . 6. W. latiflos Distal portion of corolla tube not markedly saccate and without a perpendicular bend above the short proximal tube; limb markedly 2-lipped, the two upper lobes fused for more than half their length and held erect, the three lower lobes deflexed; inflorescence bilateral . . . . . . . . . . . . . 7. W. preussii

7. Calyx lobes subulate, about as long as the proximal cylindrical portion of the corolla tube, $1.2-1.8 \mathrm{~cm}$ long 4 . W. laurentii Calyx lobes subulate, oblong, lanceolate or oblanceolate, longer than the proximal portion of the corolla tube, the latter gradually expanding and not exceeding $1 \mathrm{~cm}$ long $\ldots \ldots \ldots \ldots$

8. Bracteoles chartaceous, broadly ovate to orbicular, $11-20 \times 7.5-17 \mathrm{~mm}$, inserted on a short pedicel up to

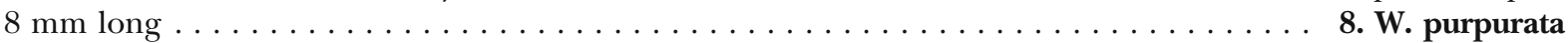
Bracteoles membranous or not, ovate, lanceolate or elliptic, usually shorter than $10 \mathrm{~mm}$ long, or if longer then membranous and inserted on a longer pedicel $(9-) 11-18(-25) \mathrm{mm}$ long $\ldots \ldots \ldots$

9. Leaves subtending the inflorescence particularly long, $17-28 \mathrm{~cm}$ long; terminal inflorescences dense and rather short, up to $8 \mathrm{~cm}$ long; flowers orange to red; calyx lobes with yellow stipitate . . . . 9. W. rutilans Leaves subtending the inflorescence shorter than $17 \mathrm{~cm}$ long; without the above combination of characters 10

10. Bracteoles $2-4.5 \mathrm{~mm}$ wide; calyx lobes linear; inflorescences dense, nodes separated by less than $10 \mathrm{~mm}$ above

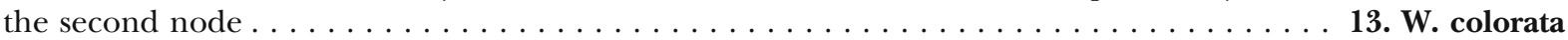
Bracteoles 5 - $11 \mathrm{~mm}$ wide; calyx lobes linear, oblong or oblanceolate; inflorescences less dense, nodes separated by more than $10 \mathrm{~mm}$ above the second node. . . . . . . . . . . . . . .

11. Pedicels pubescent; bracteoles chartaceous; sepals puberulent to pubescent; corolla bright orange to salmon

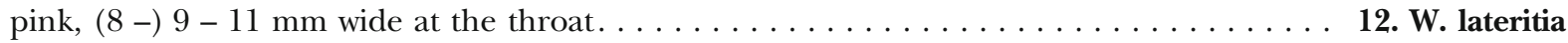
Pedicels glabrous; bracteoles membranous; calyx lobes glabrous or with sessile glands; corolla either uniform and light yellow to pale orange or green-yellow with dark purple to brown streaks, $6.5-8(-10)$ mm wide at

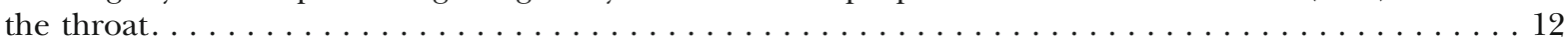

12. Corolla green-yellow with purple to dark brown longitudinal streaks. . . . . . . . . . . . 10. W. thollonii Corolla pale yellow to light orange, without darker streaks .

11. W. brazzae

1. Whitfieldia elongata (P.Beauv.) De Wild. E T.Durand (in Durand \& De Wildeman 1899: 110); Clarke (1899: 66); Durand \& Durand (1909: 421); Andrews (1956: 191); Dale \& Greenway (1961: 19); White (1962: 383); Heine (1963: 398; 1966: 34); Champluvier (1985: 492); Iversen (1991: 162); Evrard \& Demillecamps (1992: 90); Beentje (1994: 610); Cheek et al. (2011: 120); Agnew (2013: 270);
Lebrun \& Stork (1997: 507); Friis \& Vollesen (2005: 456); Ensermu Kelbessa (2006: 395); Vollesen (2008: 268; 2013: 175); Bloesch et al. (2009: 54); Lejoly et al. (2010: 22); Darbyshire et al. (2015: 354) 三 Ruellia elongata P.Beauv. (De Beauvois 1804: 46) $\equiv$ Dipteracanthus elongatus (P.Beauv.) Nees (1847: 140); Bentham in Hooker \& Vogel (1849: 478). Type: Benin, fl., s.d., Palisot de Beauvois s.n. 
(lectotype $\mathrm{G}^{*} \mathrm{G} 00378064$, selected here; isolectotype $\left.\mathrm{G}^{*} \mathrm{G} 00378063\right)$. Fig. 1A.

Whitfieldia longifolia T.Anderson (1863: 27) nom. illegit:; Moore (1880: 229) as "longiflora"; Clarke (1899: 66); Hiern (1900: 811); De Wildeman (1910: 267; 1912: 479); Hutchinson \& Dalziel (1931: 248); Type: Fernando Po [Bioko], fl., 1860, Mann 198 (lectotype K! K001208521, selected by Vollesen 2008: 268). Additional syntypes - all from Fernando Po [Bioko]: fl., s.d., Barter 2069 (K!); fl., s.d., Mann s.n. (K! K000394212); fl. Nov. 1841, Vogel 187 (K! K000394210) \& Vogel 242 (K! K000394211).

Whitfieldia perglabra C.B.Clarke (1899: 66) 三 Whitfieldia longifolia T.Anderson, var. perglabra (C.B.Clarke) Hutch. \& Dalziel (in Hutchinson \& Dalziel 1931: 248). Type: Fernando Po [Bioko], fl., 1861, Mann s.n. (holotype K! K000394212).

Whitfieldia subviridis C.B.Clarke (1899: 66). Type: D. R. Congo, Lisha [Lishia], fl. 7 July 1888, Hens 343, (lectotype K! K001208522, selected here; isolectotypes $\mathrm{P}^{*} \mathrm{P} 00439326$ \& $\left.\mathrm{P} 00439327\right)$. Additional syntypes: Nigeria, Igbessa, fl. Jan. 1893, Millen 141 (K! K001208523); Nigeria, Lagos, fl., s.d., Millen 195 (K! K001208524) \& Millen 181 (n.v.); Nigeria, Old Calabar, Robb s.n. (n.v.); Cameroon, Yaunde [Yaounde], Zenker 547 (n.v.); Fernando Po [Bioko], fl., 1860, Mann 198 (K! K001208521); Angola, Golungo Alto, Rio de Capopa, fl., s.d., Welwitsch 5151 (K! K001009241); Kenya, Mombasa, fl. Nov. 1884, Wakefield s.n. (K! K001208565).

Whitfieldia elongata (P.Beauv.) De Wild. \& T.Durand var. dewevrei De Wild. \& T.Durand (in Durand \& De Wildeman 1899: 111) 三 Whitfieldia longifolia T.Anderson var. dewevrei (De Wild. \& T.Durand) C.B.Clarke (1900: 511). Type: D. R. Congo, Mobanga, fl. Feb. 1896, Dewèvere s.n. (lectotype BR* BR0000013100476, selected here; isolectotypes BR BR* BR0000013100315 \& BR0000013100315).).

Whitfieldia tanganyikensis C.B.Clarke (1899: 67). Type: Zambia, Tanganyika Plateau, "Moero Plateau", fl., 1894, Carson 22 (lectotype K! K000394205, selected here). Additional syntypes: Uganda, Buddu, fl., 1893, Scott-Elliot 7528 (BM! BM013400585, K! K000394206).

Whitfieldia elongata De Wild. \& T.Durand var. abbreviata Mildbr. (in Robyns 1943: 88). Type: D. R. Congo, Kabasha, fl. 7 Dec. 1934, de Witte 2162 (holotype BR* BR0000008740618; isotype BR* BR0000006493547).

For a description of this species see Vollesen (2013: 175).

DISTRIBUTION. This species is found from western and central Africa in Benin, Nigeria, Cameroon, Central African Republic, Equatorial Guinea (Bioko), Gabon,
Congo Republic, D. R. Congo and Rwanda, to eastern Africa in South Sudan, Ethiopia, Uganda, Kenya and Tanzania and southern Africa in Zambia and Angola (Map 1). It is also cultivated in Zimbabwe according to Maroyi (2006).

Whitfieldia elongata is the most widespread and common species in the genus. Many specimens belonging to this species have already been listed in Evrard \& Demillecamps (1992) for Central Africa and Vollesen (2008) for East Africa. Additional collections are cited below for each country where it is currently found in the wild, restricted to one citation per country.

SELECTEd COLlections Studied. Benin. Ouémé, Dangbo Forest, fl. 12 Nov. 1999, Maesen 6822 (WAG* WAG0063277). NIGERIA. Abeokuta Prov., Egbado Distr., Ilaro F. R., fl. 17 Dec. 1952, Onochie in FHI 31888 (K!). CAMEROON. Village de Mebanga, près Mpandang, fl. 21 Feb. 1959, Letouzey 1492 (K! K001208564, P* P03590321, YA YA00066833!). CENTRAL AFRICAN REPUBLIC. Sangha pref., Ndakan, fl. 2 Jan. 1988, Harris E Fay 37 (K!, WAG* WAG.1237268, US* US02856868). EQUATORIAL GUINEA. Bioko, Malabo-Baney (along the maritime coast), road km 17, fl. 19 Nov. 1988, Carvalho 3718 (K!, MA). GABON. Belinga, fl. 8 June 1966, Hallé 3769 (K!, P* P03032863). CONGO REPUBLIC. R. Alima, fl. Sept. 1887, Thollon 952 (P* P03590262). D.R. CONGO. Kasai Distr., village of Malela, about 50 - 60 km S of Pania Mutombo, fl. 28 June 1934, Becquaert 2 (K!). RWANDA. Parc Nat. Kagera, territoire annexe, environs de Kakitumba, fl. 3 July 1957, Troupin 3674 (BR* BR0000013100605). SOUTH SUDAN. Imatong Mountains, Talanga, fl. 1 Dec. 1980, Friis $\mathcal{E}$ Vollesen 598 (C, K!). ETHIOPIA. Keffa, ridge between swamp 15 mins walk beyond village and c. 2.5 hrs walk W of Mizan Teferi, fl. 15 Jan. 1976, Gilbert 4234 (ETH, K!). UGANDA. Budongo Forest, fl. Dec. 1934, Eggeling 1467 (K!). KENYA. Shimba Hills, Pengo Hill, Kidomo, fl. 25 Jan. 1979, Bamps 6343 (BR* BR0000020158385, WAG* WAG.1237353). TANZANIA. East Usambara, Muheza road below Siggi (Amani), fl. 12 Dec. 2011, Hemp 5403 (K!). ZAMBIA. nr. Nchelengi, L. Mweru, fl. 26 April 1951, Bullock 3843 (K!). ANGOLA. Loanda, Canzengo, fl., s.d., Gossweiler 4767 (K! K001009240).

HABITAT AND ECOLOGY. This species is found on the forest floor in evergreen forests, often by rivers in gallery forests or along forest tracks or roads. It starts as a shrub and can become scandent reaching up to 3 $\mathrm{m}$. It often occurs in disturbed and secondary forest. It can be found from sea level up to $1650 \mathrm{~m}$ a.s.l.

CONSERVATION STATUS. Whitfieldia elongata is known from 15 tropical African countries with a large EOO of $6,163,812 \mathrm{~km}^{2}$. It is locally common in forest habitat, from evergreen primary forest to more 

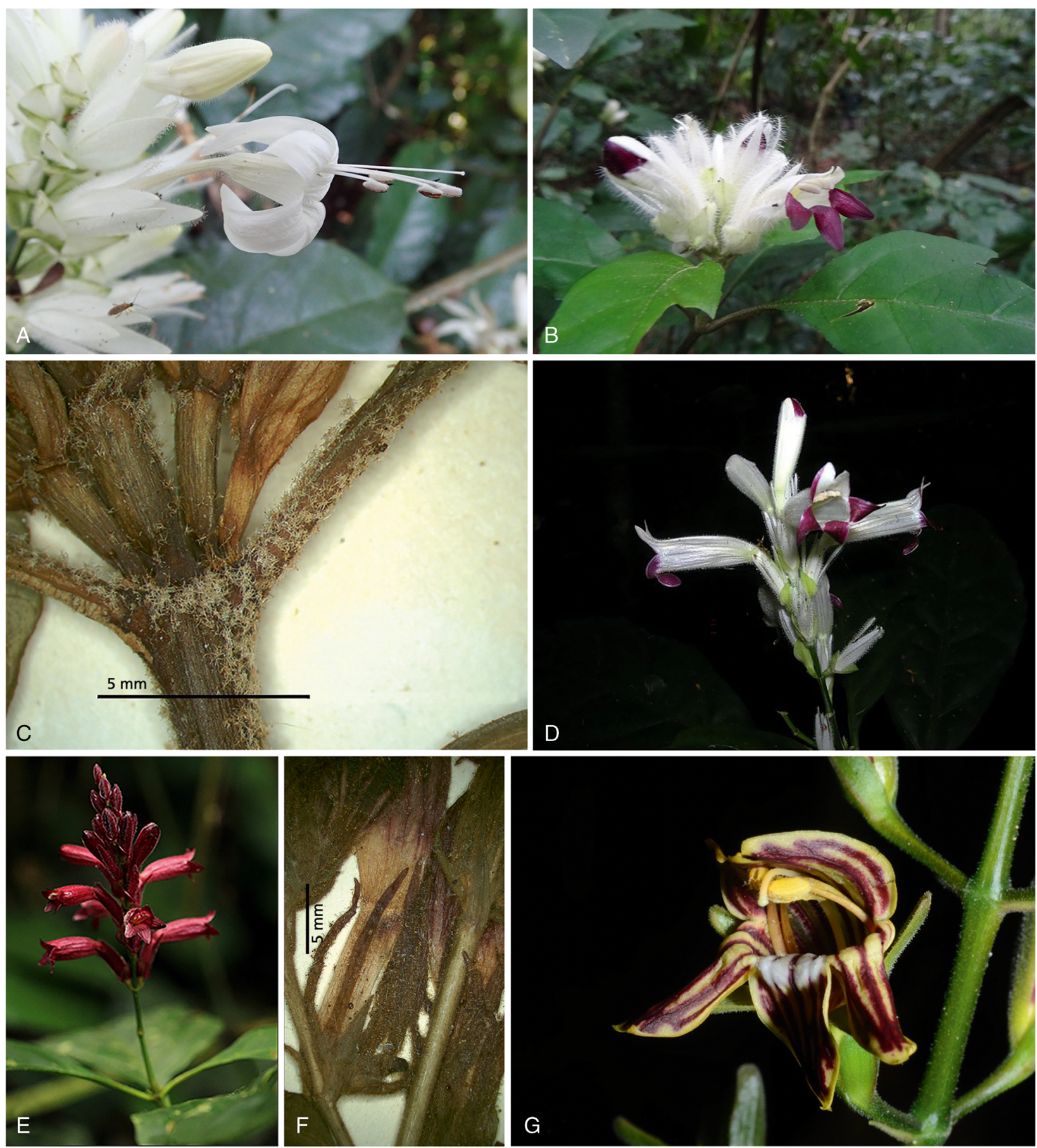

Fig. 1. Photographs of Whitfieldia in the field and in herbaria. A W. elongata, from Somalomo, at the edge of the Dja National park, Cameroon (collected as Grall 117). B - C W. orientalis: B in flower from Lindi Region, Ruawa Forest Reserve, Tanzania (collected as Suleiman H.O.S. 5534); C detail of stem indumentum, from Verdcourt \& Greenway 256 (K). D W. stuhlmannii, from D. R. Congo (collected as Luke 7562); E W. laurentii, from D. R. Congo (collected as Würsten 4814A); F W. liebrechtsiana, bracteoles, calyx and partial corolla from Gossweiler 8049 (K); G W. preussii, from Gabon (collected as Bidault 1496). PHOTOS: A A. GRALL; B I. DARBYSHIRE; D Q. LUKE; E B. WÜRSTEN; G E. BIDAULT.

disturbed areas such as along roads and by villages. Therefore, it is considered to be of Least Concern (LC).

NOTES. (1) The flowers of Whitfieldia elongata, with its pure white corolla and long and narrow basal tube, look like typical moth-pollinated flowers (Evrard \& Demillecamps 1992; A. Giusti, pers. comm.). Although only rarely recorded (Tanner 2413 [K!, BR], Grall 117 [YA!, K!, P!, WAG!]), the flowers are subtly fragrant. We expect them to open fully at night, as suggested by 


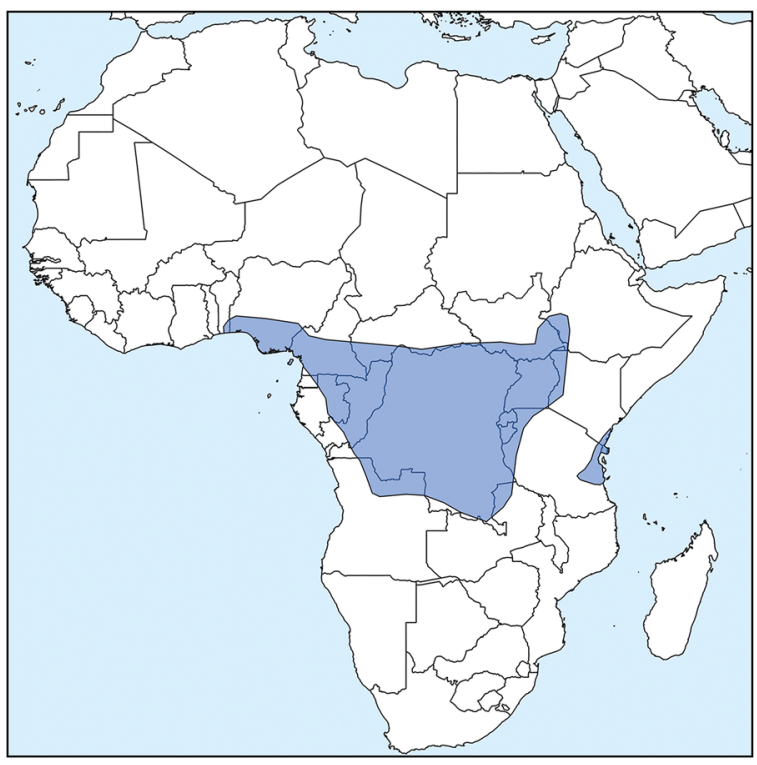

Map 1. Distribution of Whitfieldia elongata in Africa.

its local name in digo (Kenya, Tanzania) "Mkula usiku" translated as "grow by night" (Pakia 2006).

The pollen of this species is spheroidal with $6-9$ scattered pores (Manktelow et al. 2001) and spinules on its surface. This is an unusual pollen type for this genus as all other species have a flattened, biporate, smooth pollen type (Evrard \& Demillecamps 1992; Mankletow et al. 2001). While all other Whitfieldia species are said to be bee-pollinated (Mankletow et al. 2001; D. Notton, pers. comm.), W. elongata has a white long tubular corolla with exserted stamens typically associated with moth-pollination (sphingophily) (Faegri \& van der Pijl 2013). The unusual pantoporate pollen structure could potentially be the result of the co-evolution of this species with a moth pollinator. However, this still needs to be tested.

(2) When Anderson (1863: 27) published the name Whitfieldia longifolia, he cited the collections of Barter, Vogel and Mann from Fernando Po (= Bioko) in the Hooker Herbarium. Subsequently, Clarke (1899: 66) separated those same collections into four species: W. elongata, W. perglabra, W. longifolia and W. subviridis. In F.T.E.A, Vollesen (2008: 270) chose the collection Mann 198 (K) as lectotype of W. longifolia. However, Mann 198 was also cited by Clarke (1899: 67) as one of the syntypes of $W$. subviridis. For clarity, W. subviridis is lectotypified here using one of the other syntypes listed by Clarke, namely Hens 343 .

(3) The protologue of Ruellia elongata P.Beauv. (De Beauvois 1804: 46) describes flowers of a 'beautiful blue sky colour' as depicted on the plate associated with the description of the species (De Beauvois 1804: tab. XXVI). However, not only should the flowers in this case have been described as and painted white, but they also should show a slight bend at the apex of the corolla tube and four longer and fully exserted stamens on the plate (instead of straight corollas with two short stamens). Such inaccuracies in the description and illustration could be justified by the poor state of the original collection (Palisot de Beauvois s.n.). However, faulty colouring of some of the plates in De Beauvois's Flore d'Oware et de Benin has first been reported in Marshall (1951). Later, Brenan (1952) described several of those plates as 'simply products of the imagination and sadly misleading to the botanist' (p. 194).

2. Whitfieldia orientalis Vollesen (2004: 123; 2008: 267; 2013: 173); Burrows et al. (2018: 882, 889). Type: Tanzania, Lindi Distr., Rondo Plateau, fl. 10 Feb. 1991, Bidgood et al. 1458 (holotype K! K000780517; isotypes C, CAS, DSM, K! K000780518, NHT). Figs 1B - C.

Whitfieldia stuhlmannii sensu Clarke (1900: 68), quoad Heinsen 17, Holst 2673, 3297, Volkens 2396, non Lindau.

For a description of this species see Vollesen (2013: 173).

DISTRIBUTION. This species is known from the East African coast from southern Kenya, Tanzania and northern Mozambique (Map 2).

ADDitionAl COLLECTIONS STUdied. KENYA. Mwele Ndogo Forest, Shimba Hills, fl. 6 Jan. 1988, Luke 893B (EA, K!); Kwale, Shimba hills, fl. 12 Sept. 1997, Luke 4729 (EA, K!). TANZANIA. Lindi Distr., Sudi, fr. 25 May 1943, Gillman 1460 (K!); Tanga Prov., Mkulumuzi valley near Amboni caves, fl. 8 June 1950, Verdcourt E Greenway 256 (BM!, BR* BR0000020159108, EA, K!, P* P03032899, PRE!); Morogoro Distr., Liwale Valley, Nguru Mts., fl. 27 March 1953, Drummond E Hemsley 1842 (K!, PRE!); Kange Forest, fl. \& fr. 27 Aug. 1955, Faulkner 1704 (BR* BR0000020159085, EA, K!, PRE!); Pangani Distr., Msubugwe Forest, fr. 19 June 1956, Tanner 2919 (K!, P* P03032896); Muheza Distr., S of East Usambara Mts, Tongwe F. R., the NE part of the reserve, fl. 2 May 1987, Iversen et al. 87166 (K!, UPS); Iringa Distr., Luhega F.R. , fl. 24 Feb. 1997, Hørlyck $\mathcal{E}^{\circ}$ Jøker TZ387 (K!); Lindi Region, Mtama Distr., Ruawa F.R., off the main road between Lindi and Nangurukuru junction at Kilangala B village, fl. 18 Jan. 2020, Suleiman et al. H.O.S.5534 (DSM!, K!, NHT!). MozambiQue. Cabo Delgado Prov., c. $10 \mathrm{~km}$ from Nangade on road to Mueda, 23 March 2009, Burrows E E Burrows 11315 (BNRH, K! K000787849); $16 \mathrm{~km}$ S of Nangade, 23 March 2009, Lotter E Turpin 1764 (K! K000787857).

HABITAT AND ECOLOGY. Whitfieldia orientalis is recorded from seasonally moist lowland evergreen or semideciduous forest from near sea level to $800(-1000) \mathrm{m}$ a.s.l. It occurs mainly in undisturbed forests, although it 


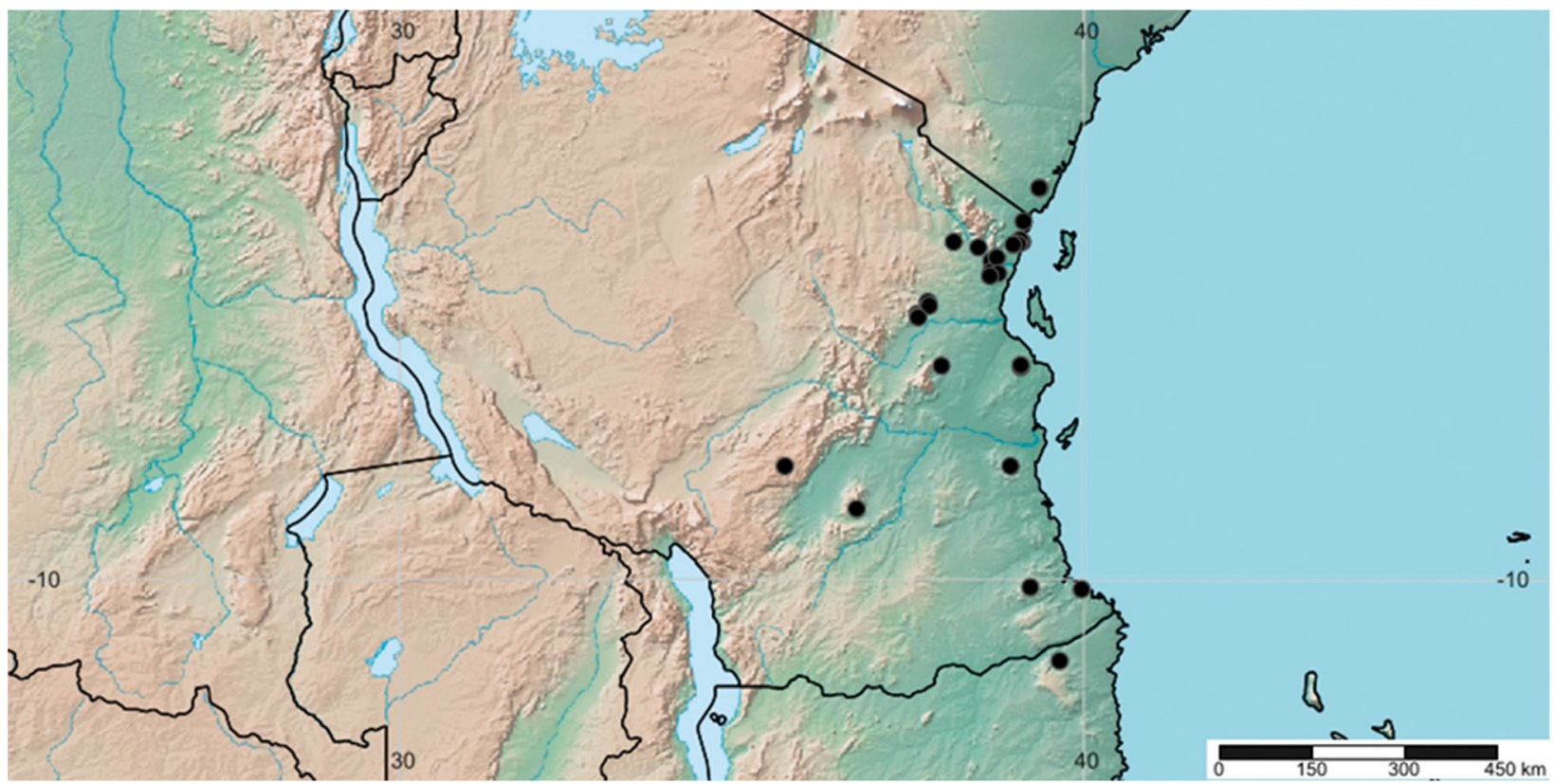

Map 2. Distribution of Whitfieldia orientalis in Kenya, Tanzania and Mozambique.

can also be found in a more fragmented habitat. Detailed notes on the habitat, ecology and phytogeography of this species are recorded by Vollesen (2004).

CONSERVATION STATUS. This species occurs in forest patches in coastal lowland East Africa. It has an EOO of $194,731 \mathrm{~km}^{2}$ and an AOO of $116 \mathrm{~km}^{2}$, based upon using the standard recommended grid size of $2 \times 2$ $\mathrm{km}^{2}$. Whilst this calculated AOO is likely to be an underestimate of the true AOO because of incomplete sampling, it is probably not grossly so since the sizes of the extant forest patches within its range are small and declining due to forest clearing for conversion to agriculture, production of charcoal, timber logging, pole cutting and fuelwood gathering (Burgess \& Clarke 2000). We have identified 17 to 20 locations for this species, and whilst this number is almost certainly declining, it is not close to meeting the threatened category thresholds under Criterion B. With further research, this taxon might qualify as threatened under Criterion A as some parts of its range have experienced over $30 \%$ forest loss of tree cover since 2000. However, in the absence of more information at present, this species is considered to be of Least Concern (LC).

NOTES. Many East African herbarium collections previously identified as Whitfieldia stuhlmannii have been redetermined as $W$. orientalis. The latter is easily distinguished from the former by its tufts of floccose stellate hairs (see Fig. 1C) covering the young stems, its shorter basal, cylindrical portion of the corolla tube and its shorter inflorescences $(1-7 \mathrm{~cm}$ long vs $5-10$ $\mathrm{cm})$. Moreover, the two white upper corolla lobes in $W$. orientalis are almost completely fused, whereas they are clearly divided in W. stuhlmannii.
3. Whitfieldia stuhlmannii (Lindau) C.B.Clarke (1899: 68); Durand \& Durand (1909: 422); Evrard \& Demillecamps (1992: 92); Vollesen (2008: 268); Lejoly et al. (2010: 23) 三 Stylarthropus stuhlmannïLindau (1894: 11; 1895: 306). Types: D. R. Congo, Isange-Semliki, fl. 8 Dec. 1891, Stuhlmann 2963 (holotype B $\uparrow$ ); between Bobata and Kamango, fl. Nov. 1939, Gille 286, (neotype BR* BR0000008740656, selected by Vollesen 2008). Fig. 1D.

Whitfieldia seretii De Wild. (De Wildeman 1910: 267;

1912: 479). Type: D. R. Congo, road from Duru to Rungu, fl. 7 Jan. 1907, Seret 739 (holotype BR* BR0000008510105).

Whitfieldia seretii De Wild. var. elliptica De Wild. (De Wildeman 1912: 479). Type: D. R. Congo, dans les forêts autour du poste de Yanga, fl., Jan. 1910, Jespersen s.n. (holotype BR* BR0000008512734).

For a description of this species see Vollesen (2008: 268).

DISTRIBUTION. This species is known from the forests of central and western D. R. Congo and in eastern Tanzania. In 2018, it was also found for the first time in Rwanda (Fischer 577/2018, see below). It may also occur in western Uganda in the forests of the Semliki National Park, close to the type locality, and might also be found in Burundi, but no collections of Whitfieldia stuhlmannii are known from those countries to date (Map 3).

ADDITIONAL COLLECTIONS STUDIED. D. R. CONGO. Route Amadi - Suronga, fl. 13 Dec. 1905, Séret 350 (BR* BR0000013109189， BR0000008509901 \& BR0000013109196); Kamusuku, territoire de Shabunda, fl. \& fr. 18 Aug. 1959, Léonard 5926 (BR* 


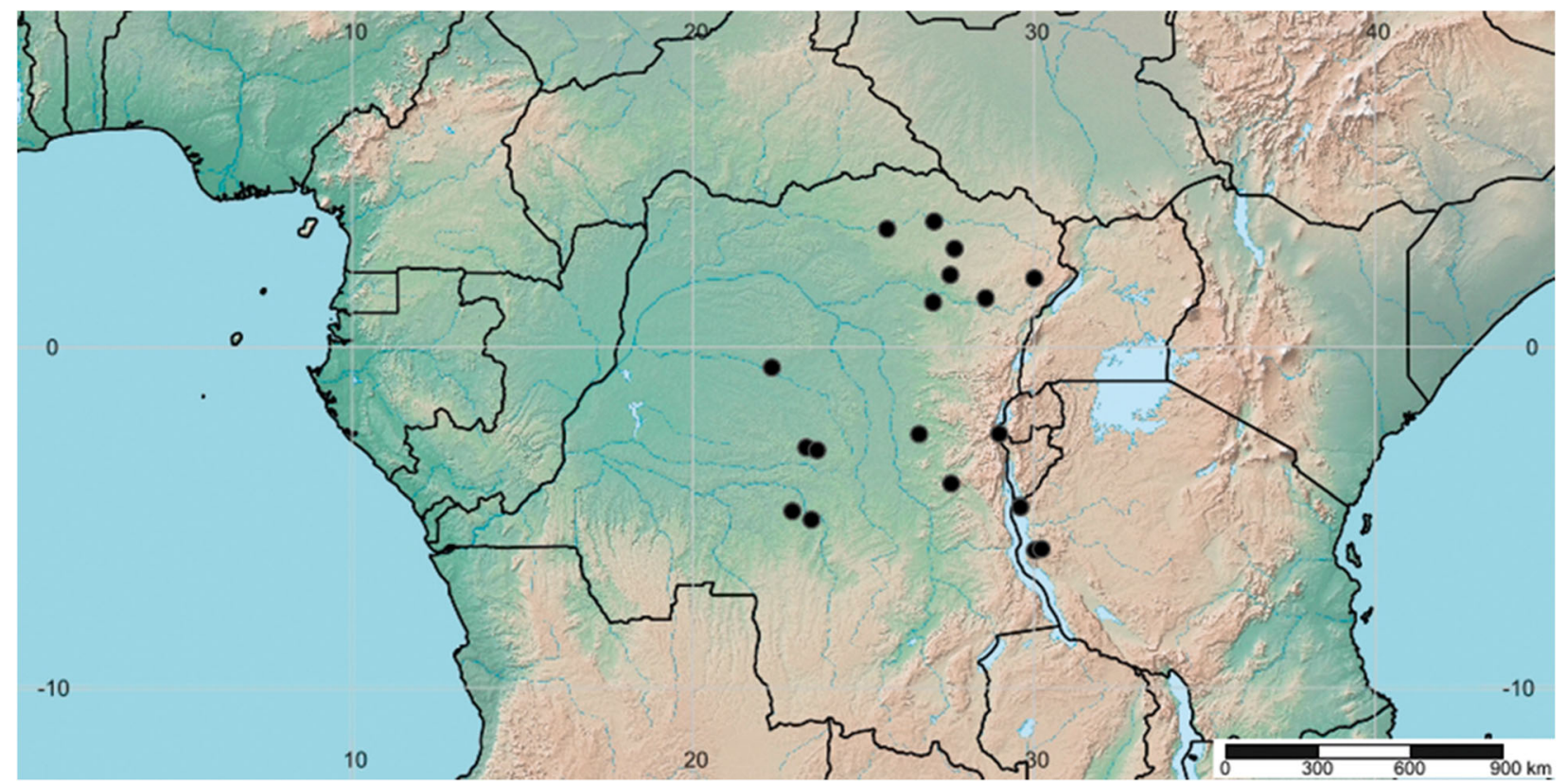

Map 3. Distribution of Whitfieldia stuhlmannii in D. R. Congo and Tanzania.

BR0000013109219); Maniema prov., Namoya, Explor. Camp to Kibiswa, fl. 10 Aug. 2008, Luke 12414 (BR* BR0000015255976, EA, K!, MO); Ituri prov. Mongbwalu, N of Msisi village, fl. 24 Jan. 2011, Bytebier 3295 (EA, EPU, BR* BR0000013366476, K!); Haut-Uele prov., Asonga Hill, c. 75 km S of Isiro, fl. 4 Aug. 2011, Ndjango 693 (EPU, K! K000683903). RWANDA. Western Province, Nyungwe National Park, Cyamudongo Forest, close to road towards Nyakabuye on N-exposed slope, fl. 15 May 2018, Fischer 577/2018 (KOBL**). TANZANIA. Kigoma Distr., Gombe Stream Reserve, upper Mkenke, fl. 29 April 1992, Mbango 1032 (K!); Kigoma Distr., Mt Livandabe [Lubalisi], fl. 3 June 1997, Bidgood et al. 4285 (K! 2 sheets); Mpanda Distr., Ntakatta Forest, fl. 14 June 2000, Bidgood et al. 4678 (K!).

HABITAT AND ECOLOGY. Whitfieldia stuhlmannii grows in wet, undisturbed or somewhat disturbed forest. It is commonly found by streams in riverine forests, and occurs at 750 - $1300 \mathrm{~m}$ a.s.l.

CONSERVATION STATUS. This species has been collected in Tanzania and D. R. Congo, with a large EOO of $735,508 \mathrm{~km}^{2}$. However, except for three collections, most of the Congolese collections are old with little or outdated locality information, hence not all are mapped. In addition, eastern Congo has been under-collected and so we cannot use the calculated AOO $\left(68 \mathrm{~km}^{2}\right)$ as a suitable measure for this assessment. A decline in the forest cover is ongoing within the range of Whitfieldia stuhlmannii due to conflict and mining operations in D. R. Congo (Butsic et al. 2015). Of the two known localities in Tanzania, Ntakatta Forest is protected as a Forest Reserve whilst Mount Livandabe is not protected. However, there is still considerable intact forest cover within the EOO of W. stuhlmannii at present. Moreover, even though most collections are from primary forests, a few specimen labels mention that this species can tolerate some disturbance ("forêt secondaire" or "Hevea"). Based upon those observations, this species is assessed as of Least Concern (LC).

4. Whitfieldia laurentii (Lindau) C.B.Clarke (1899: 68); Evrard \& Demillecamps (1992: 98); Lejoly et al. (2010: 23) $\equiv$ Stylarthropus laurentii Lindau (1897: 317); De Wildeman \& Durand (1899: 65, t.32). Type: D. R. Congo, forêts près Stanley falls, fl. 20 Jan. 1896, Laurent s.n. (lectotype BR! BR0000008393074, selected here; isolectotype BR! BR0000006494193). Fig. 1E.

Whitfieldia arnoldiana De Wild. \& T.Durand (in Durand \& De Wildeman 1899: 116); synon. nov.; De Wildeman (1910: 266; 1912: 479) Evrard \& Demillecamps (1992: 99); Lejoly et al. (2010: 22). Type: D. R. Congo, forêt des environs de Stanleyville, fl. 24 Dec. 1896, Dewèrre 1159a (holotype BR! BR000000839340).

Leiophaca purpurea Lindau (in Friedrich 1911: 307). Type: D. R. Congo, Aruwimi, Yambuya, fl. May 1908, Mildbraed 3288 (holotype BR* BR000000839501).

For a description of this species see Whitfieldia arnoldiana in Evrard \& Demillecamps (1992: 99)

DISTRIBUTION. This species is known from the forests of the northeastern equatorial region of D. R. Congo (Map 4). 
SELECTED COLLECTIONS STUDIED. D. R. CONGO. Injolo, fl. Oct. 1905, Laurent 1423 (BR! BR0000008393678); Chemin de Buta à Banalia, fl. 14 Jan. 1926, Robyns 1359 (K!); Plateau entre l'Isalowe et l'Ilongo à l'est de Yangambi, fl. 4 Jan. 1936, Louis 936 (K!, P! P03590308, PRE!); Yangambi, fl. 18 Feb. 1957, Leonard 158 (BR* BR0000013397098, K!); Yangambi, fl. 28 Dec. 1937, Louis 7256 (K!, P! P03590309); Parc National Albert, confluent Djuma/Semliki, fl. 18 Feb. 1948, de Wilde 174 (K!); Kibati, terr[itoire] Walikale, fl. 13 June 1957, Gutzwiller 1148 (BR* BR0000013396718); Route Kavumu - Walikale, vers $\mathrm{km} \mathrm{110,} \mathrm{Irangi,} \mathrm{réserve}$ IRSAC [Institut pour la Recherche Scientifique en Afrique Centrale], fl. 6 Nov. 1959, Troupin 10981 (BR* BR0000013396794); Yangambi, fl. 30 Jan. 1960, Devred 4007 (BR* BR0000013397227, K!).

HABITAT AND ECOLOGY. Whitfieldia laurentii has often been collected by water in riverine forests, in the shade of primary to more degraded forests and in forests clearings, at $400-1650 \mathrm{~m}$ a.s.l.

CONSERVATION STATUS. Although restricted to D. R. Congo, this species has an extensive EOO, calculated at $203,528 \mathrm{~km}^{2}$. Apart from two recent collections by B. Wursten in 2012, most collections of Whitfieldia laurentii were made prior to 1983 and the eastern part of the D. R. Congo where it grows remains undercollected. It is therefore likely that a larger number of populations than those known from herbarium specimens exists in D. R. Congo, hence we are not using the calculated AOO $\left(96 \mathrm{~km}^{2}\right)$ for assessing this species. A decline in the forest cover is ongoing within the range of $W$. laurentii due to conflict and mining operations in eastern D. R. Congo (see Butsic et al. 2015). However, forest maps show that extensive forest cover still exists within this species' range, and it is thought to tolerate some disturbance, as evidenced by specimen labels. Based upon those observations, this species is currently assessed as of Least Concern (LC).

NOTES. Evrard \& Demillecamps (1992: 90) distinguished Whitfieldia laurentii from $W$. arnoldiana by its "non-coloured" [green] calyx and its yellow and densely pubescent corolla. However, the colour of the calyx for each species is mentioned in neither protologue and on none of the specimen labels of the original material of $W$. laurentii. As for the corolla, we have studied the three collections of $W$. laurentii cited by Evrard \& Demillecamps, together with several collections of $W$. arnoldiana and did not find a significant difference in the pubescence. However, we do agree that dried specimens identified as $W$. laurentii have a paleyellow corolla, distinct from specimens filed under $W$. arnoldiana on which the dark burgundy of the flowers is clear from both our observation of dry material and the original label information. For W. laurentii, none of the labels mention the original colour of the corolla and Lindau (1897) did not specify the corolla colour when describing Stylarthropus laurentii. The pale colour of the dry material could be due to the drying technique employed by E. Laurent. Alternatively, it could also be that those three specimens are a white-flowered form of a predominantly burgundy-flowered species, i.e. that the pigmentation has been lost, a common occurrence in Acanthaceae (Tripp \& Manos 2008). Both W. laurentii and $W$. arnoldiana have the same type locality: Stanley Falls, now known as Boyoma Falls, in D. R. Congo. We conclude that separating these two species purely on the hypothesis of a different corolla colour is not justifiable

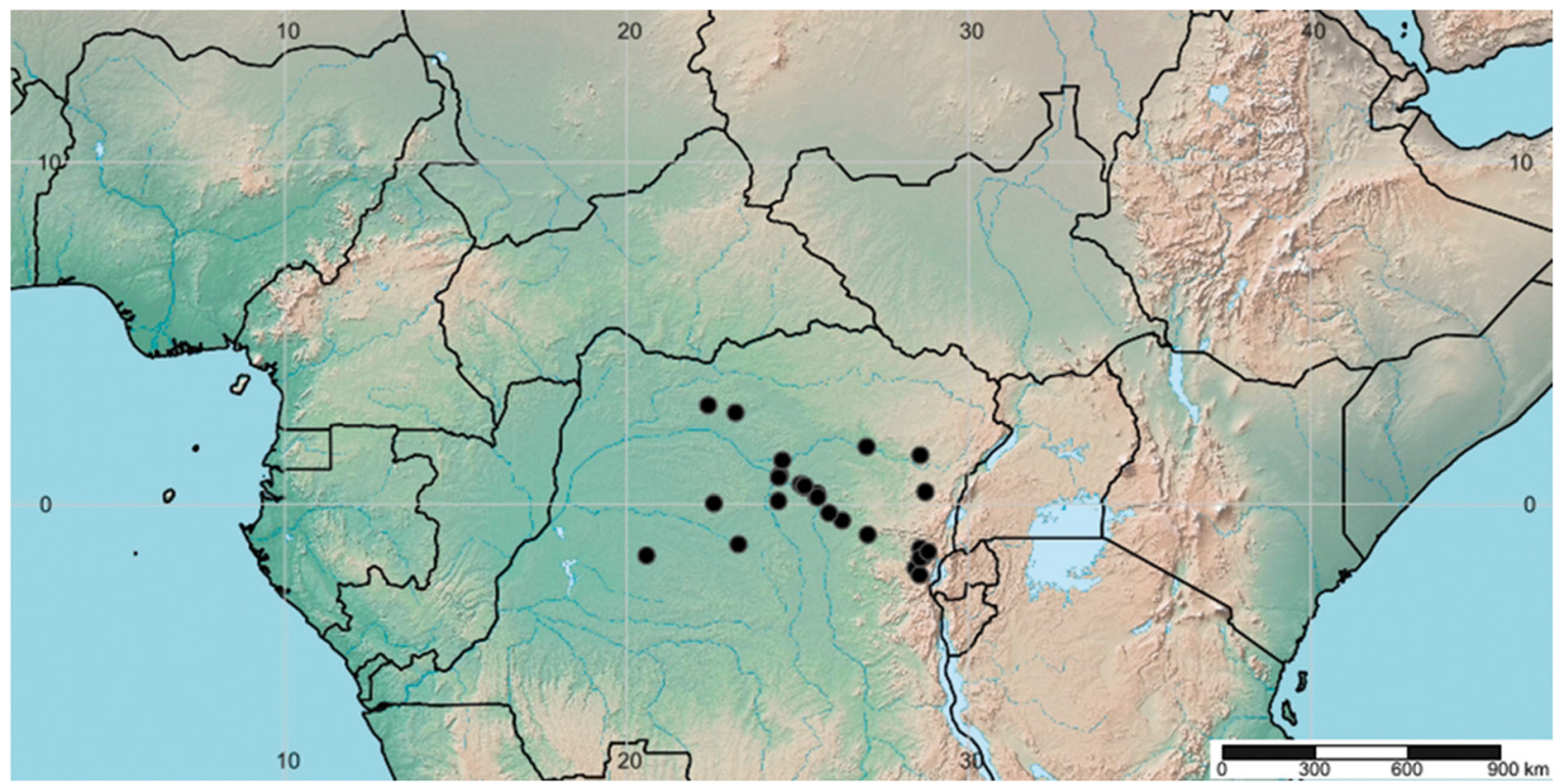

Map 4. Distribution of Whitfieldia laurentii in D. R. Congo. 
and so they should be treated as a single species under the earlier name, W. laurentii.

Whitfieldia laurentii is also very similar to W. stuhlmannii in many respects: inflorescence size, corolla shape and pubescence of the different elements of the flower. Lindau (1894), when describing $W$. laurentii, also noted that these species were very similar but that $W$. laurentii has hairy bracteoles, a character that we have not observed on the dry material of $W$. laurentii. Lindau also added that the inflorescences of $W$. laurentii are pauciflorous and axillary, but this distinction is not obvious from our own observation of the two taxa. However, the flowers of W. stuhlmannii always show a very clear colour pattern on the corolla with its distinctive purple lobes contrasting sharply with the pure white tube and throat, and the corollas of W. stuhlmannii are generally larger than those of $W$. laurentii (c. $24-59 \mathrm{~mm}$ long, vs $20-25 \mathrm{~mm}$ long).

5. Whitfieldia liebrechtsiana De Wild E T.Durand (in Durand \& De Wildeman 1899: 111); Durand \& Durand (1909: 422); Evrard \& Demillecamps (1992: 98) Type: D. R. Congo, on the road from Owali to Chiganga, fl. 20 Aug. 1895, Dewevre 277 (holotype BR* BR0000008393227). Fig. 1F.

Asystasia striata S.Moore (1930: 133) $\equiv$ Whitfieldia striata (S.Moore) Vollesen (in Furness \& Vollesen 1991: 731). Type: Angola, Cabinda, Buco Zau, fl. 31 July 1916, Gossweiler 6540 (holotype BM! BM000931035).

For a description of this species see Evrard \& Demillecamps (1992: 98).

DISTRIBUTION. This species is known from the Mayumbe (Mayumba, Mayombe or Maiombe) forests that extend from the south of Gabon, through Congo Republic, the region of Cabinda in Angola and into the western tip of D. R. Congo (Map 5).

ADDITIONAL COLLECTIONS STUDIED. CONGO REPUBLIC. Madingou, Moyen-Congo, fl. July 1950, Koechlin 1209 (P! P03032900); Mayume (M. Congo), Boku-n' Situ, fl. 8 Aug. 1951, Koechlin 1548 (P! P03032909); Kouilou, Bilala, fl. 21 June 1989, Dechamps 13078 (BR* BR0000013442972); Kouilou, Les Sara, fl. 29 June 1989, Dechamps 13182 (BR* BR0000013442729). D. R. CONGO. Kiniati, près de Lukula, fl. 15 Sept. 1912, Chevalier 28436 (P! P03032908); Boma-Sundi (Lukula), fl. 29 Aug. 1913, Bequaert 641 (BR* BR0000013109202); ANGOLA. CABINDA. Buco Zau, fl. 31 July 1916, Gossweiler 6540 (BM! BM000931035); Sera-Subluali-Maiombe, fl. 9 May 1919, Gossweiler 8049 (BM! BM000931036, K!, LISC* LISC048221, LISC048221, LISC048223, LISC048224, LISC048225 \& LISC048226); entre Buco
Zau e Belize, in bud, 27 Aug. 1958, Monteiro et al. 245 (PRE!); Buco Zau, Chiaca, fl. 15 June 1959, Monteiro E Murta 16 (PRE!); Maiombe-Chiaca, Buco Zau, fl. 15 July 1959, M.E.F.A 434 (LISC* LISC048227, LISC048228).

HABITAT AND ECOLOGY. Whitfieldia liebrechtsiana grows in shade in lowland forests and plantations (banana, cocoa) from near sea level to $180 \mathrm{~m}$ a.s.l.

CONSERVATION STATUS. The EOO calculated for Whitfieldia liebrechtsiana of $10,702 \mathrm{~km}^{2}$ is well below the $20,000 \mathrm{~km}^{2}$ threshold for Vulnerable under criterion B1 and only eight locations are recorded. This species is largely an endemic of the Mayombe with one subpopulation in Aubeville (Congo Republic). Widespread logging for timber, construction, firewood and charcoal, and for clearing areas for subsistence agriculture is a serious threat to the biodiversity of the Mayombe Forest. In addition, the impact of slash and burn cultivation practice is a major concern in this region (Ron 2013). Transfrontier Conservation Areas in this region have been designated and could secure the future of Mayombe species, an area known to be of high botanical importance (Romeiras et al. 2014). No collections have been made in the area since 1989 and recent observations or collections are needed to confirm its current status in the Mayombe region today. As for the Aubeville area in Congo Republic where the species was collected in 1951, the forest has since suffered from industrial wood exploitation (1953 - 1988), exploitation of goods and services by local communities, and finally, since 1988, strong pressure from slash and burn agriculture (Kimpouni 2008). Currently, W. liebrechtsiana is not known from any protected areas (Protected Planet 2020) and considering the small number of locations and the continuing decline in extent and quality of habitat, it is assessed as Vulnerable under criterion B: VU Blab(iii,v).

NOTES. With its long subulate bracteoles (see Fig. 1F), long slender inflorescences and its corolla which is purple in its upper half, becoming striped with purple lines in the middle and then transitioning to cream/ white, Whitfieldia liebrechtsiana is unlikely to be confused with any other species.

6. Whitfieldia latiflos C.B.Clarke ex Stapf (1906: 640). Type: Liberia, within 20 miles of Kakatown [Kakata], fl., 1904, Whyte s.n. (holotype K! K000394214).

Whitfieldia lateritia sensu Hutchinson \& Dalziel (1931: 399), pro parte quoad Whyte s.n. ex Liberia.

Shrub, up to $150 \mathrm{~cm}$ tall; leafy stems stout, $4-5 \mathrm{~mm}$ in diam., somewhat 4-angular or becoming terete, swollen above nodes (constricted in dry state), shortly pubescent when young with multicellular spreading 


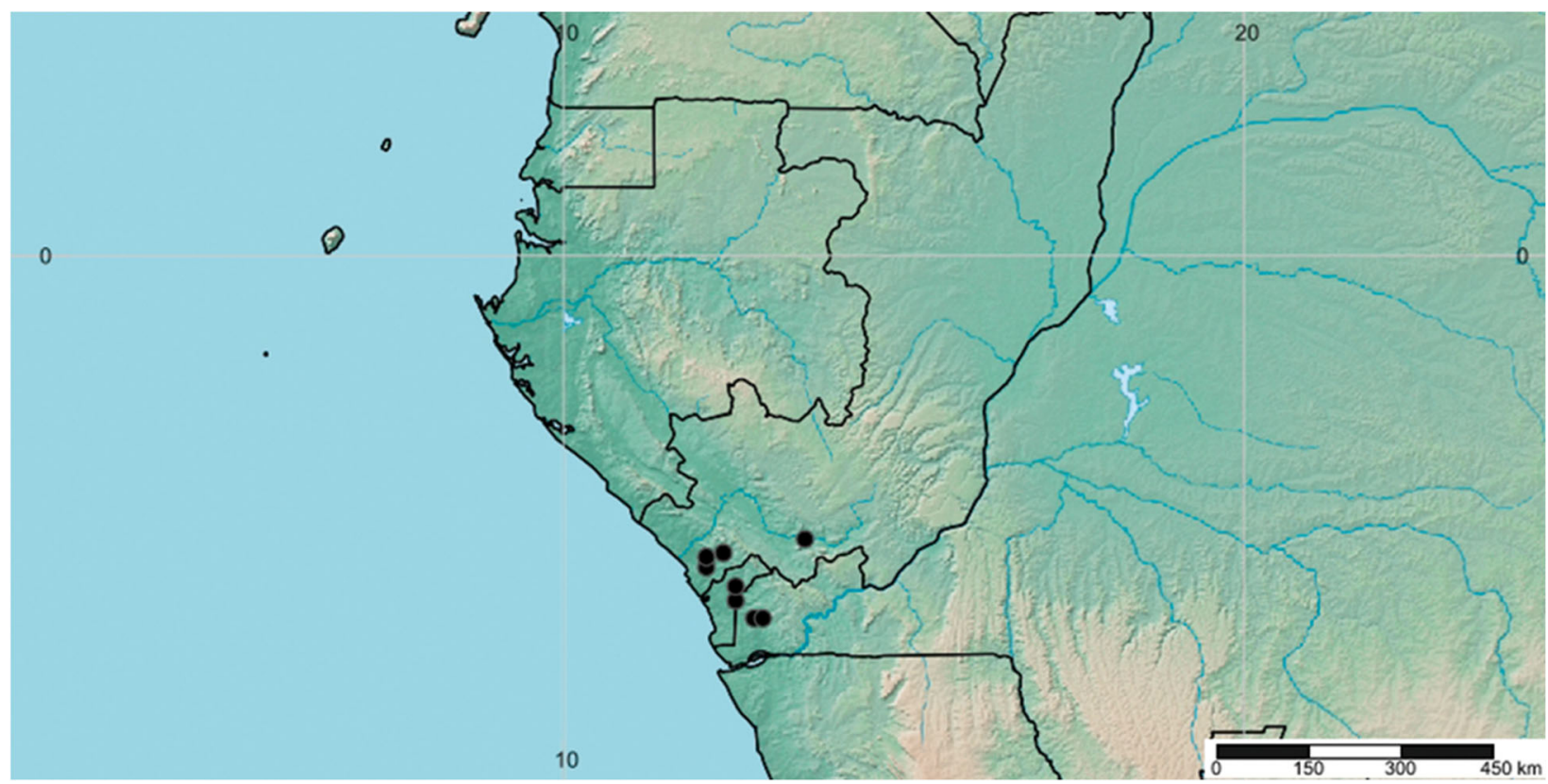

Map 5. Distribution of Whitfieldia liebrechtsiana in Congo Republic, Cabinda (Angola) and D. R. Congo.

hairs, later glabrescent. Leaves petiolate, petiole 1.5 $4 \mathrm{~cm}$ long, shortly pubescent; blade oblong-elliptic, c. $16.5-19 \times 6.5-8.2 \mathrm{~cm}$, base shortly attenuate then abruptly widened, margin entire, apex shortly acuminate; lateral veins c. $8-9$ pairs, these and midrib pale and prominent beneath; shortly pubescent on main veins beneath, elsewhere glabrous; cystoliths minute, dot- or shortly rod-shaped, surface beneath also with minute sunken dark glands. Inflorescences axillary in distal leaf axils, racemiform, $3.7-13 \mathrm{~cm}$ long, secund; primary peduncle $9-30 \mathrm{~mm}$ long, this and spike rachis pubescent with short multicellular hairs, these appearing deflated in dry state; cymes at each inflorescence axil single-flowered, opposite, becoming \pm widely spaced at maturity; bracts along rachis green, linear or narrowly lanceolate, $(4.5-) 7-13 \times 0.6-3$ $\mathrm{mm}$, shortly pubescent beneath, glabrous above; pedicels of individual cymes 1.5 - $3.5 \mathrm{~mm}$ long, densely short-pubescent; bracteole pairs fused towards base, clasping the calyx, each pale yellowish-green, broadly ovate, $7-11 \times 7-8.5 \mathrm{~mm}$, base rounded or shallowly cordate, apex obtuse or shortly and bluntly acuminate, external surface shortly pubescent, internal surface glabrous; flowers sessile above bracteoles. Calyx divided to the base into five oblong-oblanceolate lobes, pale yellowish-green but darker towards apices, lobes somewhat unequal in size, posterior lobe largest, $9.5-11.7 \times 3.6-4.5 \mathrm{~mm}$, other four lobes marginally smaller and narrower, each with apex rounded and surface with 3 or 5 subparallel veins, both surfaces glandular-pubescent. Corolla reddish-purple, lobes and distal portion of tube speckled purple and with darker purple veins, $\pm 21.5 \mathrm{~mm}$ long when dissected and flattened, glabrous externally; basal portion of tube somewhat bulbous, $3.7-4.5$ long and $4.3-5 \mathrm{~mm}$ in diam., above which tube is slightly constricted and bent through c. $90^{\circ}$, and abruptly expanded into markedly saccate throat 11.5 - $13 \mathrm{~mm}$ long and $10-$ $13 \mathrm{~mm}$ in diam., with few long multicellular hairs on floor within and with a raised ring of dense silky, blunt unicellular hairs at insertion point of stamens; limb of five ovate-triangular lobes in a weak $2+3$ configuration, left-contorted in bud, becoming somewhat reflexed at anthesis; adaxial pair of lobes 5.5-6.5 ×5.7-6.7 mm, slightly asymmetric, fused for $1-2.5 \mathrm{~mm}$ at base; 3 abaxial lobes $6-7.5 \times 5.5-6.5 \mathrm{~mm}$, apices slightly emarginate. Stamens 4 , didynamous, held against roof of corolla; filaments sigmoid-shaped, longer pair 10 $15 \mathrm{~mm}$ long, glabrous; anthers included within corolla tube or those of longer pair partially exserted, thecae narrowly oblong, $2.9-3.3 \mathrm{~mm}$ long, connective palepuberulous and with few short-stalked glands. Ovary 2 - $2.5 \mathrm{~mm}$ long, glabrous, within cupular disk 0.8 $1 \mathrm{~mm}$ tall; style markedly curved, held against corolla roof, $\pm 19 \mathrm{~mm}$ long, shortly pubescent in distal half; stigma capitate, $0.5 \mathrm{~mm}$ in diam. Capsule only seen in immature state, $17 \mathrm{~mm}$ long including stipe $6.5 \mathrm{~mm}$ long, fertile portion broadly expanded, rounded with obtuse apex, glabrous; seeds not seen. Fig. 2.

DISTRIBUTION. Whitfieldia latiflos is only known from two collections in the northwest of Liberia: the type was collected 20 miles from Kakata, and the second 


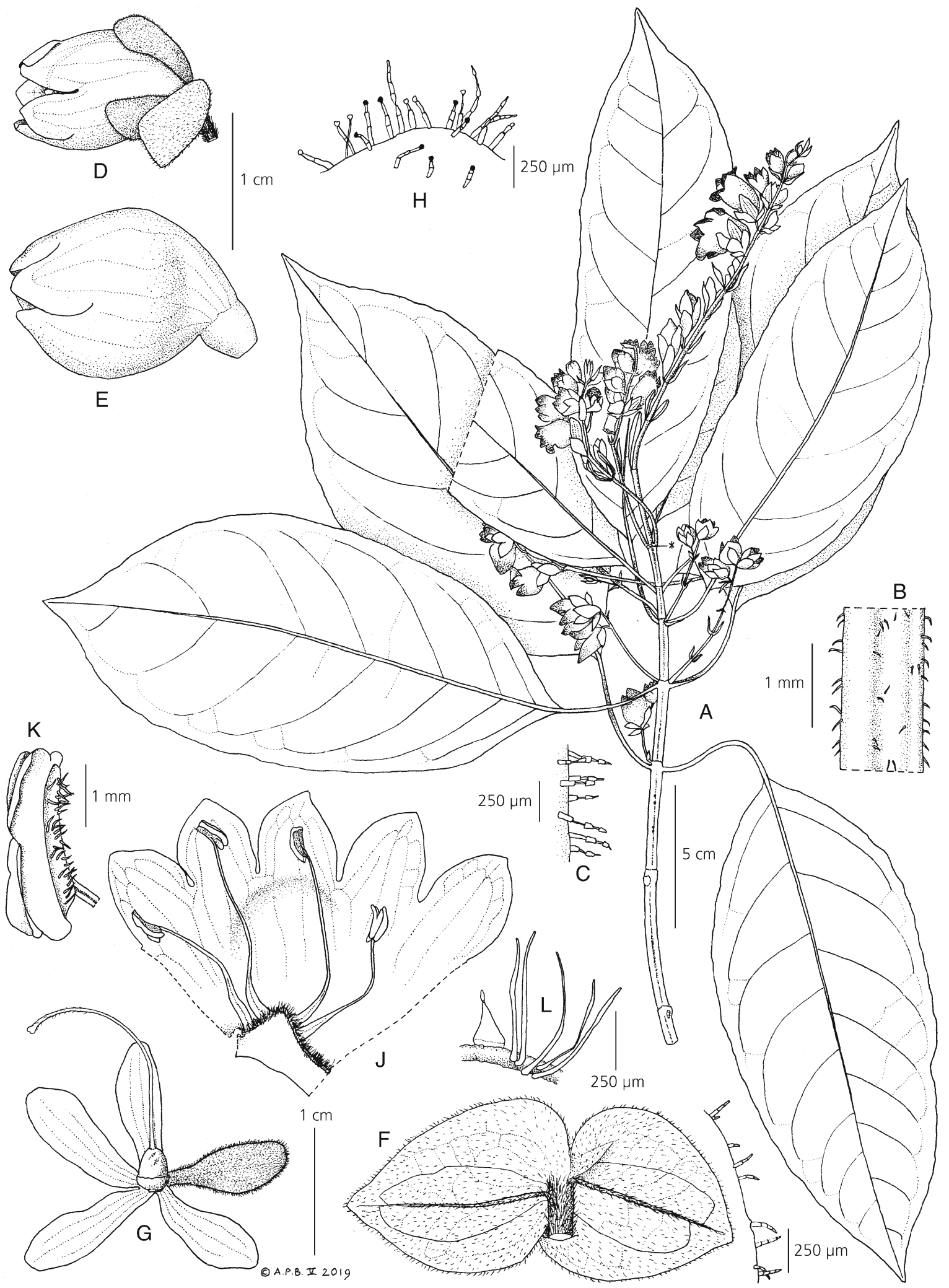

Fig. 2. Whitfieldia latiflos. A habit, flowering stem; note leaf at * removed to reveal inflorescences; B petiole, adaxial channelled surface; $\mathbf{C}$ detail of pedicel indumentum; D recently opened flower; $\mathbf{E}$ detail of the corolla of a recently opened flower showing the sharply angled ventral surface; F bracteoles with detail of indumentum at margin on the right; $\mathrm{G}$ calyx with ovary, style and stigma; $\mathrm{H}$ indumentum of calyx at margin; $\mathbf{J}$ corolla cut and opened flat, dorsal corolla lobe on the right; $\mathrm{K}$ detail of anther; $\mathrm{L}$ detail of staminode with part of raised ring supporting filaments, with examples of attached hairs. A - F, H - L from Baldwin 10754 from Genna Tanyehun, Liberia; ovary, style and stigma in G from Whyte s.n. from Kakatown, Liberia. DRAWN BY ANDREW BROWN. 
specimen was from Genna Tanyehun in Grand Cape Mount County (Map 6).

ADDITIONAL COLLECTION STUDIED. LIBERIA. Grand Cape Mount Co., Genna Tanyehun, fl. 20 Dec. 1947, Baldwin 10754 (K!).

HABITAT AND ECOLOGY. Very little of the ecology of Whitfieldia latiflos is known: no altitude or habitat information features on the labels of the two known collections. However, given what we know about the localities, it is likely to occur in moist forest.

CONSERVATION STATUS. This species, which has not been collected since 1947, is only known from two localities, hence no EOO could be calculated. It has been collected only twice despite reasonable botanical coverage in Liberia, indicating that it is a rare species. However, the northern collecting site (Baldwin 10754) is close to the Gola Forest National Parks (on the Liberia-Sierra Leone border) where the species may be found in the future. The southern collecting site (Whytes.n.) is near Kakata, which today is a highly modified and degraded area due to urban expansion and agriculture. We cannot be sure that this location has been lost but the possibility for this is high. There is a clear need for rediscovery of this species, with efforts focusing in and around the Gola National Parks for conservation purposes. At present, with only two collecting sites known and a clear and ongoing threat to one of these, we assess this species as Endangered: EN B2ab(iii).

NOTES. This species was reduced to synonymy within Whitfieldia lateritia by Hutchinson \& Dalziel (1931) in the First Edition of Flora of West Tropical Africa, whereas
Heine (1963) did not refer at all to $W$. latiflos in the Second Edition. Heine had presumably not seen Baldwin 10754 when preparing his treatment of Whitfieldia for that publication. The type of $W$. latiflos is a rather depauperate specimen, with the corolla being somewhat immature, but the Baldwin collection is a much better specimen, with fully mature corollas that are clearly distinct from both $W$. lateritia and W. colorata C.B.Clarke ex Stapf. In fact, W. latiflos is more likely to be confused with $W$. preussii (Lindau) C.B.Clarke in the colour and form of the corolla. However, it differs in having an externally glabrous corolla which becomes saccate in its upper part. Moreover, the corolla limb of $W$. latiflos is only weakly 2-lipped whereas in $W$. preussii this is markedly bilabiate (Table 1).

7. Whitfieldia preussii (Lindau) C.B.Clarke (1899: 67); Heine (1963: 399); Cheek et al. (2004: 142, 231); Onana \& Cheek (2011: 76); Velayos et al. (2013: 114) 三 Stylarthropus preussii Lindau (1894: 12; 1895: 306 307). Type: Cameroon, buschwald ostlich von lake, Barombi, fl. 12 Sept. 1890, Preuss 516 (holotype B $\uparrow$; lectotype K! K000029101, selected here; isolectotypes K! K000029102, BM!). Fig. 1G.

Whitfieldia letestui Benoist (1928: 671) synon. nov.; Heine (1966: 44); Lachenaud et al. (2018: 397). Type: Gabon, Yaouri, fl. 30 May 1915, Le Testu 2066 (lectotype P! P00439329!, selected here; isolectotypes BM! BM000931037!, BR! BR000006294182 \& BR000006289836, IFAN* IFAN16582, K! K000394209, P! P00439328, P00439330).

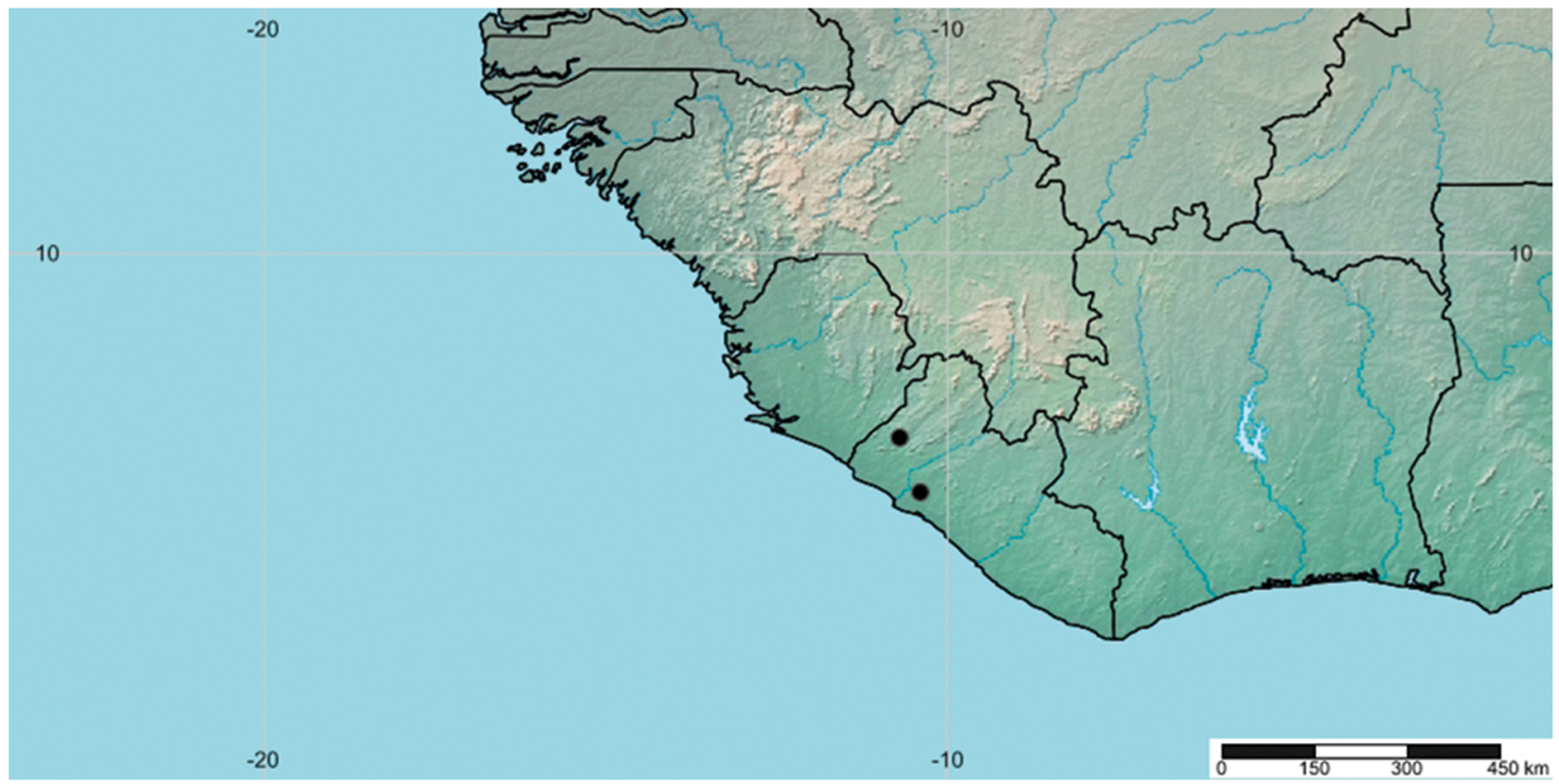

Map 6. Distribution of Whitfieldia latiflos in Liberia. 
Table 1. Diagnostic characters separating Whitfieldia latiflos from $W$. preussii.

\begin{tabular}{|c|c|c|}
\hline Character & $W \cdot$ preussii & W. latiflos \\
\hline Corolla indumentum & Pubescent externally & Glabrous externally \\
\hline Corolla limb & $\begin{array}{l}\text { Markedly 2-lipped, the two adaxial lobes fused for } \\
\text { more than half their length and held erect, } \\
\text { three abaxial lobes deflexed }\end{array}$ & $\begin{array}{l}\text { Weakly 2-lipped, adaxial lobes fused for less than } \\
\text { half their length, abaxial lobes slightly reflexed } \\
\text { but not markedly deflexed }\end{array}$ \\
\hline Corolla tube & $\begin{array}{l}\text { Throat gradually expanded and curved above the } \\
\text { basal tube, not markedly saccate }\end{array}$ & $\begin{array}{l}\text { Throat abruptly expanded above and held at a } \\
\text { marked angle to the basal tube and markedly } \\
\text { saccate }\end{array}$ \\
\hline Calyx indumentum & Minutely glandular- and eglandular-puberulent & Glandular-pubescent \\
\hline Anthers & All four anthers exserted from corolla tube & $\begin{array}{l}\text { Only anthers of longer pair of stamens exserted, or } \\
\text { all anthers included within corolla tube }\end{array}$ \\
\hline Style & $\begin{array}{l}\text { Conspicuously pubescent distally with long white } \\
\text { hairs }\end{array}$ & Shortly pubescent distally \\
\hline $\begin{array}{l}\text { Bracts along inflorescence } \\
\text { rachis }\end{array}$ & $\begin{array}{l}\text { Minute, linear-lanceolate, curved, } 1.8-4 \text { mm long, } \\
\text { drying dark brown }\end{array}$ & $\begin{array}{l}\text { Linear or narrowly lanceolate, not curved, }(4.5-) 7 \\
-13 \mathrm{~mm} \text { long, drying green }\end{array}$ \\
\hline $\begin{array}{l}\text { Pedicels of individual } \\
\text { flowers (single-flowered } \\
\text { inflorescence units) }\end{array}$ & $3-12 \mathrm{~mm}$ long, puberulent or sparsely so & $1.5-3.5 \mathrm{~mm}$ long, densely pubescent \\
\hline
\end{tabular}

For a description of this species see Whitfieldia letestui in Heine (1966: 44).

DISTRIBUTION. Whitfieldia preussii is found in the southwestern regions of Cameroon and Gabon as well as on the island of Bioko in Equatorial Guinea (Map 7). We are not aware of any specimens from the continental part of Equatorial Guinea (Río Muni) and from the Congo Republic but it is quite possible that this species also occurs in those countries.

ADDITIONAL COLLECTIONS STUDIED. CAMEROON. Bipindi, fl. 1900, Zenker 2229 (BM!, K! K000461084, P! P03032904); Bipindi, fl., 1902, Zenker 2461 (BR* BR0000020159122, K! K000461085, P! P03032907 \& P03032903, WAG* WAG.1237413); Bipindi, fl., 1913, Zenker 4668 (BM!, K! K000461083, P! P03032906); Eseka, fl. 11 Dec. 1967, Bamps 1405 (BR* BR0000020159139, YA! YA0061292); $36 \mathrm{~km} \mathrm{~N}$ of Kribi, Edea Falls, fl. 30 Dec. 1969, Bos 6017 (WAG* WAG0160822, P! P03032905); Kumba area, fl. 13 Oct. 1984, Thomas Eे Nemba 4050 (MO, K! K000029100, YA); Matoh, fl. 25 Aug. 1986, Mambo E̋ Thomas 122 (MO, K! K000029099, YA); Meme Div., Moungo, fl. 24 Oct. 1998, Etuge 4321 (BR* BR0000009556447, K! K000109347, MO, P! P04445952, US, WAG* WAG.1237412, YA); Ebo Forest Research station, Bekob drinking stream trail, fl. 27 Oct. 2006, Osborne 197 (K! K000634564, WAG* WAG.1237411, YA); Ebo proposed National Park, fl. 10 Nov. 2007, Fenton 231 (K! K000616978, YA). EQUATORIAL GUINEA. BIOKO. Malabo - Luba, km 42, fl. 2 Dec. 1989, Carvalho 4211 (K! K000518533). GABON. Rabi-Kounga, fl. 14 May 1992, Breteler 11438 (WAG* WAG.1975250); Ogooué-Maritime, Toucan, 14 June 2002, Bourobou 746 (LBV); Ngounié, Sindara, 22 June 2011, Bissiengou et al. 1439 (WAG* WAG.1975251); Zone de Mabounié, à environ $45 \mathrm{~km}$ au sud-est de Lambaréné, rive est de la
Ngounié, fl. 6 May 2012, Dauby 2731** (LBV); loc. ibid., fl. 9 May 2014, Bidault 1496 (BR! BR0000024389563, BRLU, LBV, MO); loc. ibid., fl. 10 May 2014, Bidault Eं Akouangou 1497 (LBV); loc. ibid., fl. 13 May 2014, Bidault Eं Akouangou 1512** (BRLU, LBV, MO).

HABITAT AND ECOLOGY. Whitfieldia preussii often grows along streams in wet forest at $50-830 \mathrm{~m}$ a.s.l.

CONSERVATION STATUS. Prior to this present study, Whitfieldia preussii and W. letestui were considered two different species, and a conservation assessment was available for each of them. Whitfieldia preussii was assessed as Vulnerable (VU) based upon its previously known distribution in Cameroon and Bioko (Darbyshire 2014). The species then had only eight locations and its threat status was justified by the decline in the extent and quality of its habitat due to agricultural expansion. Whitfieldia letestui was assessed as Endangered (EN), being considered endemic to southwest Gabon, with only nine specimens known from eight subpopulations. Of these, four subpopulations occur in a mining concession and two in an oil concession, both of which are experiencing some lowlevel human pressure including forest clearance, whilst a seventh subpopulation occurs in a selectively logged forest. This led to the conclusion that the quality of habitat of this species is being reduced, with only 4 locations left in total (Stévart et al. 2016).

However, these populations are treated here as a single species, and a new location, that of Ebo in Cameroon, has been added. The new EOO is now calculated as $137,816 \mathrm{~km}^{2}$ and 13 locations have been identified. Within the EOO, the species still appears to be scarce, with few suitable forests which could host this species. Moreover, as far as Cameroon is concerned, all specimens collected fall outside the range of formally protected areas that are managed for their biodiversity, such as National Parks, although 


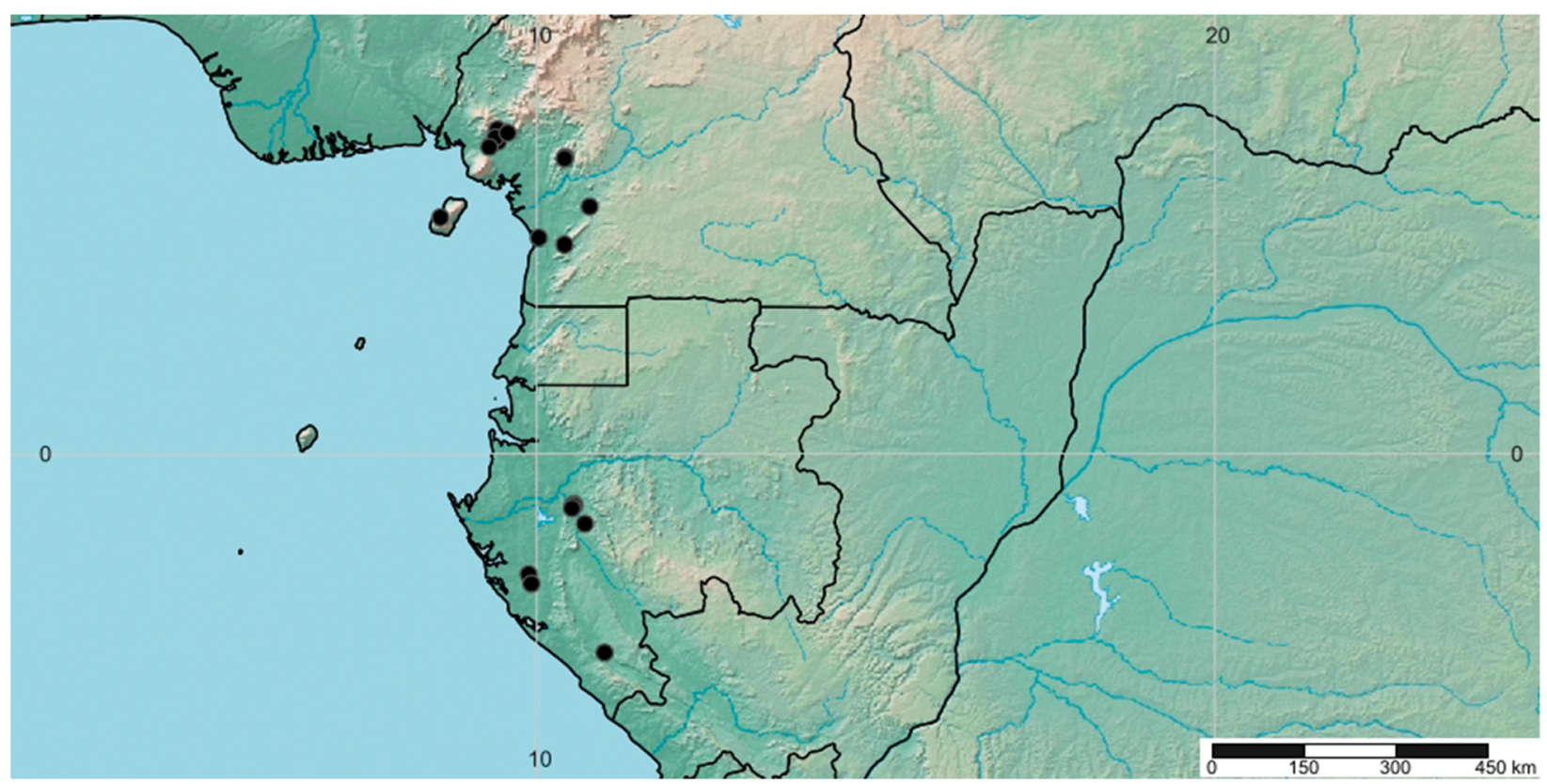

Map 7. Distribution of Whitfieldia preussii in Cameroon, Equatorial Guinea (Bioko), and Gabon.

Ebo was formerly proposed as such. Similarly on Bioko, the single known specimen of this species comes from a non-protected area. It is possible that this species is under-collected due to a short flowering period (Lachenaud et al. 2018). However, with few collections known in total and most specimens coming from non-protected areas, the species is now assessed as Near Threatened: NT B2ab(iii).

NOTES. Lachenaud et al. (2018) considered Whitfieldia letestui to be endemic to southwestern Gabon. However, Heine (1966: 44) had previously noted that this species was very close to $W$. preussii, but the scarcity of the collections prevented him from making taxonomic changes. The characters Heine cited for potentially distinguishing the two species (including the density of the inflorescence, the pilosity of the bracteoles and the length of the flower peduncle) do not clearly discriminate two taxa in the light of the collections available for study today. Consequently, following a thorough review of material identified as $W$. letestui and $W$. preussii, we conclude that these species cannot be distinguished and $W$. letestui is synonymised here.

8. Whitfieldia purpurata (Benoist) Heine (1966: 36); Wieringa \& MacKinder (2012: 148) ) Pounguia purpurata Benoist (1938: 679). Type: Gabon, Poungui, région de Lastourville, fl. 20 July 1930, Le Testu 8166 (holotype P! P0043933; isotype BM!). Fig. 3A.

For a description of this species see Heine (1966: 36).
DISTRIBUTION. Whitfieldia purpurata is endemic to the Bambidie-Lastourville area in Eastern Gabon (Map 8). ADDITIONAL COLLECTION STUDIED. GABON. Lastoursville, fl. 27 April 1929, Le Testu 7255 (BM!, BR* BR0000020159160 \& BR0000020159177, P! P03032886, P03032889).

HABITAT AND ECOLOGY. Neither the labels for the only two collections known nor the protologue of Whitfieldia purpurata give us any indication of its ecology. However, both specimens come from the Lastoursville area of Gabon, which supports evergreen humid forest (Escourrou 1988). From Google earth, (www.google.com/earth/index.html), we estimated that $W$. purpurata grows between 260 and $440 \mathrm{~m}$ a.s.l.

CONSERVATION STATUS. This species is only known from the Lastoursville area, which is currently unprotected. A good forest cover in the area still exists away from the main roads but slash and burn and mining activities are present in the Lastourville area. Much collecting has been conducted in this region, where this species has not been recollected for almost 90 years. However, in the Ogooué-Lolo province more generally, a large part of the forest remains unexplored (Jongkind 2018), and Whitfieldia purpurata could well grow in those unexplored areas. As there is currently too little knowledge on the populations of this species, it is assessed as Data Deficient (DD).

NOTES. (1) In Flore du Gabon, Heine (1966: 37) noted that the type collection (the only specimen known for 

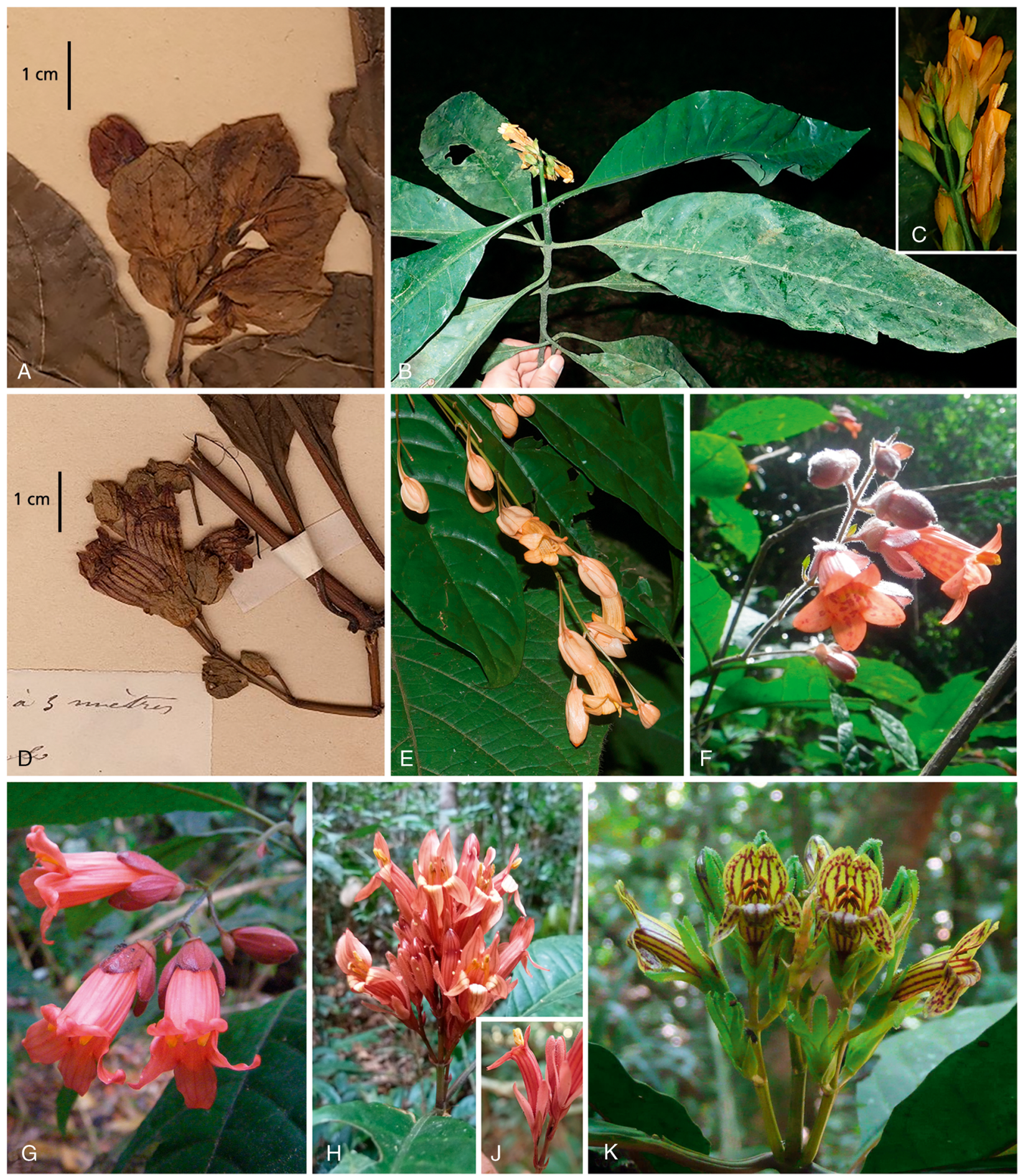

Fig. 3. Photographs of Whitfieldia in the field and in herbaria. A W. purpurata, detail of bracteoles, from Le Testu 8166 (P). B \& C W. rutilans from Ogooué-lolo, Gabon, collected as Texier 840: B habit, C detail of the inflorescence. D W. thollonii, detail of an inflorescence, from Thollon 210 (P). E W. brazzae from the Batéké plateaux, Gabon. F \& G W. lateritia: F from Kindia, Guinea (collected as van der Burgt 2184); G from Simandou, Guinea (collected as Haba 249). H \& J W. colorata subsp. colorata: H inflorescence, J flower detail, Dugbe HummingBird site (c. 20 km S of Sapo National Park, c. 50 km E of Greenville), near Tuzon, along the Geebo R., Liberia (collected as Senterre 6948). K W. colorata subsp. tigrina, Sapo National Park, Liberia (collected as Jongkind 9339). PHOTOS: B, C N. TeXIER; E J. P. VANDE WEGHE; F, G X. VAN DER BURGT; H, J B. SENTERRE; K C. JONGKIND. 


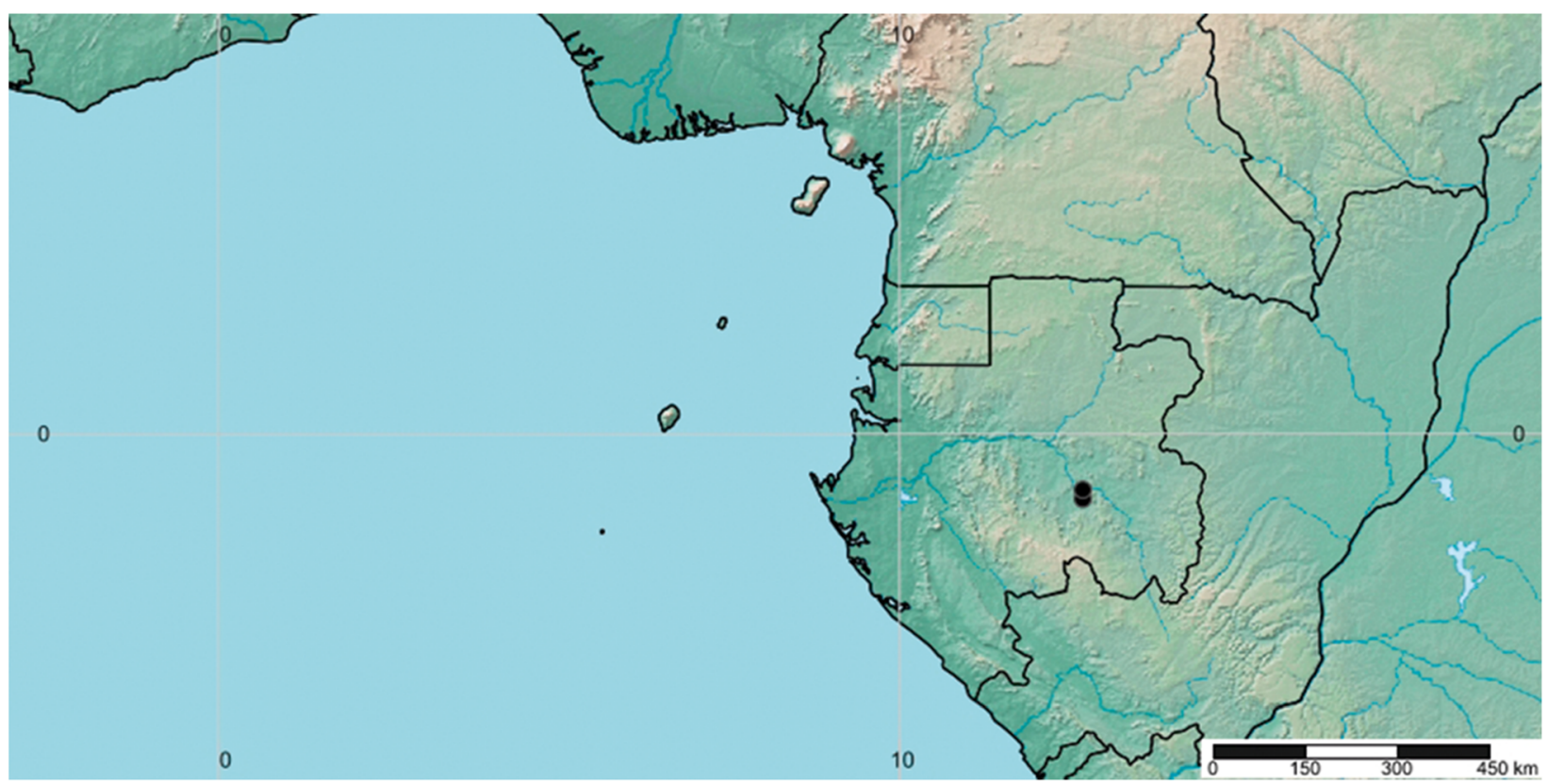

Map 8. Distribution of Whitfieldia purpurata in Gabon.

Whitfieldia purpurata at the time, see Note 2) could be an extreme form of $W$. brazzae (Baill.) C.B.Clarke with bracteoles and flowers particularly large and a glabrous inner corolla surface. However, the inflorescences of $W$. brazzae are much more lax. As for the bracteoles, with more collections of $W$. brazzae being available to us today, we observe that even though its bracteoles are wide, they are elliptic to ovate and never fully rounded such as in the type of $W$. purpurata (see Fig. 3A). Moreover, we have not seen any specimen of $W$. brazzae with a purple corolla (the corolla of $W$. brazzae varies from pale yellow to salmonpink or orange). As for the corolla inner surface, it is often also glabrous in W. brazzae, so this character does not help to separate the two species.

(2) The specimen Le Testu 7255, determined by Heine as Whitfieldia thollonii (Heine 1966: 40) was also collected in Lastoursville in Gabon. Its corolla $(25 \times 7.5$ $\mathrm{mm}$ ) is, as in W. purpurata, more campanulate than funnel-shaped. The original label describes its colour as "jaune abondamment rayée de brun [yellow heavily streaked with brown]", confirmed by the observation of the dry specimens, although the stripes are not as neat as in W. thollonii. Instead, they resemble the flowers of $W$. purpurata. Indeed, the flowers of $W$. purpurata have been described as purple on the type label but a yellowgreen corolla heavily striped with brown (or purplishbrown) lines could also be perceived as purple. Indeed, a similar case has indeed been observed in the description of corollas of W. colorata subsp. tigrina, described both as "dingy purple" and "yellow with darker red lines". However, in a dry state, the corollas of that taxon all look similar with thick blurred dark purple stripes on a cream or yellow background. This is also the case in W. purpurata. As for the bracteoles in Le Testu 7255, they are not so clearly rounded as in the type of $W$. purpurata; instead, they have a rounded to ovate base with a distinct triangular acumen. However, measurements of the bracteoles at anthesis also exceed the range of bracteoles measured in $W$. thollonii $(11-11.5 \times 7.5-8.5 \mathrm{~mm}$ vs $9 \times 7$ $\mathrm{mm})$. Since this collection is the only one so far determined as W. thollonii from Gabon, disjunct from the rest of its distribution in the Congo Republic and D. R. Congo, we believe it should be best placed under $W$. purpurata pending further observation of populations in the Lastoursville region.

9. Whitfieldia rutilans Heine (1966: 37); Jongkind \& Texier (2019: 11). Type: Gabon, Ndanda, fl. 14 June 1931, Le Testu 8858 (lectotype P! P00439332, selected here; isolectotypes BM! BM000931034, BR* BR0000006293864 \& BR0000006293215, K! K000394207 \& K000394208, P! P00439333). Fig. 3B - C.

For a description of this species see Heine (1966: 37).

DISTRIBUTION. Whitfieldia rutilans is endemic to Gabon (Map 9).

ADDITIONAL COLLECTIONS STUDIED. GABON. Sacamicanda, fl. 21 July 1930, Le Testu 8174 (P! P03032901 \& P03032902); Ogooué-lolo, fr. 17 Oct. 2015, Bidault 1991** (LBV, MO); Ogooue-lolo, Mount Ngouadi Area, fr. 26 Feb. 2017, Texier 349** (BRLU, LBV, MO); Ogooue-lolo, fl. 13 March 2017, Texier $840^{* *}$ (LBV, MO). 


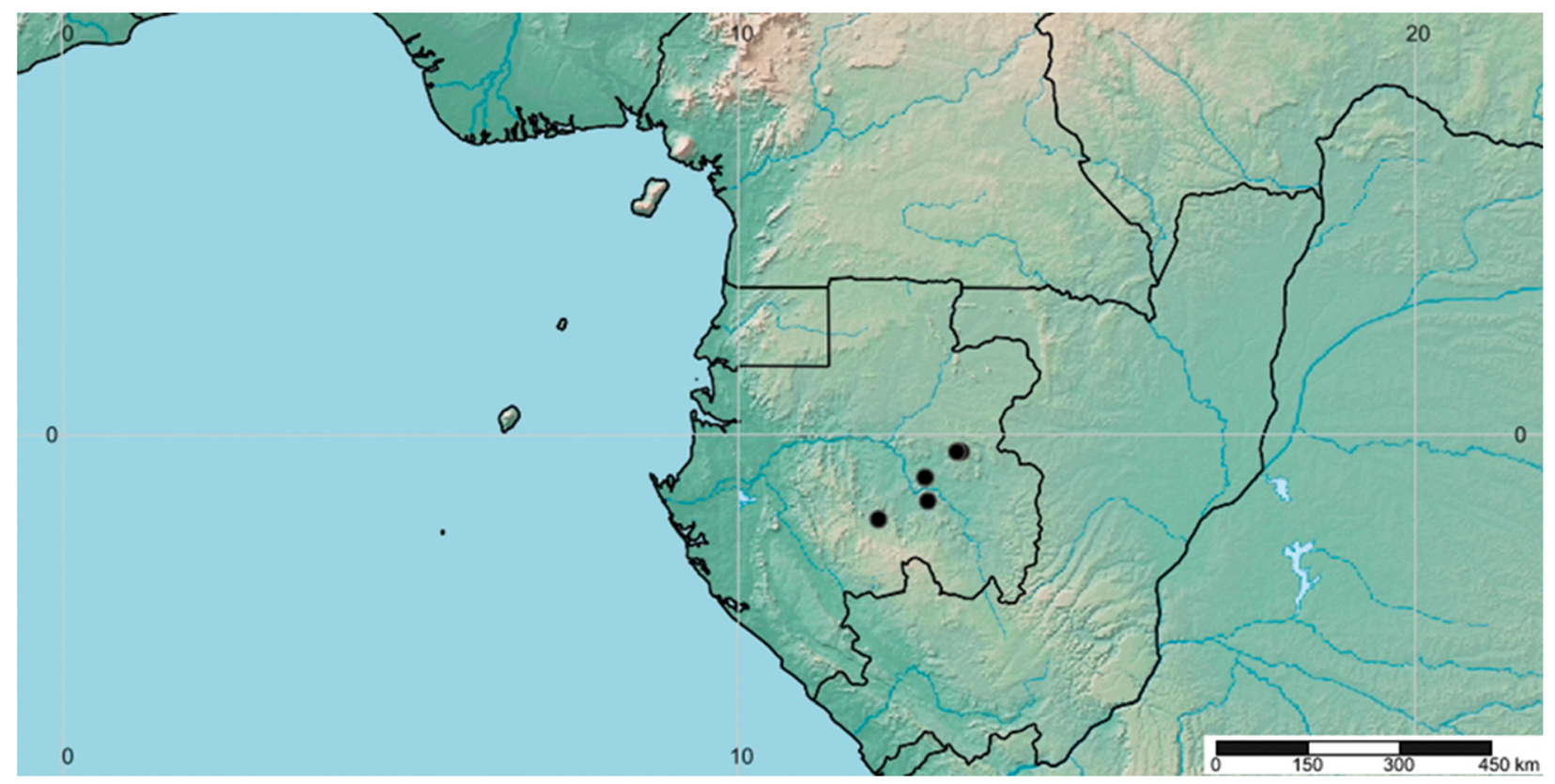

Map 9. Distribution of Whitfieldia rutilans in Gabon.

HABITAT AND ECOLOGY. Whitfieldia rutilans is a rare species which grows in evergreen forests including along riverbanks, at $300-500 \mathrm{~m}$ a.s.l.

CONSERVATION STATUS. This species was first collected by Le Testu in Ndanda and Sacamicanda in the Lastoursville area which, even though unprotected, still has a good forest cover away from major roads. More recently, Whitfieldia rutilans was rediscovered by Texier and Bidault in the same area in eastern Gabon, adding three collections from two subpopulations to the ones already known and increasing the EOO of the species to $3,046 \mathrm{~km}^{2}$. Those recent collections were made in forest logging concessions. Texier 349 and Bidault 1991 come from the SEEF concession, where the timber activity was halted in 2017 (Jongkind \& Texier 2019) and Texier 840 comes from the CEB concession where the exploitation is recent but ongoing and threatening the fourth location for this species (N. Texier, pers. comm.). More generally in this region, even though the forest loss seems low beyond the main roads, timber exploitation in this non-protected area is continuing and is expected to further affect the quality of habitat for this species. It is therefore considered here to be Endangered under criterion B: EN B1ab(iii)+2ab(iii). A preliminary assessment was already available online (Stévart et al. 2016) with the same conclusion.

NOTES. The flower colour of Whitfieldia rutilans was described by Heine (1966) as a bright ochraceous red or deep orange-red, based on the label data of the two Le Testu collections. Since then, the species has been re-collected by Texier and his photos show a pale orange corolla similar to that in some populations of
W. brazzae and W. lateritia. However, W. rutilans differs from the first species by its short pedicels, dense inflorescence and glandular calyx lobes, and from the latter by its narrower corolla $(4.2-5.5 \mathrm{~mm}$ wide vs $8-$ $11 \mathrm{~mm})$. More generally, W. rutilans is easily distinguished by its leaves reaching $28 \mathrm{~cm}$ in length (see Fig. $3 \mathrm{~B})$, which is unusually long for the genus.

10. Whitfieldia thollonii (Baill.) Benoist (1928: 671); Evrard \& Demillecamps (1992: 96) 三 Stylarthropus thollonii Baill. (Baillon 1890b: 823); Lindau (1895: 306). Type: Congo Republic, bois de Linzolo, fl., s.d., Thollon 210 (lectotype P! P00439334, selected here; isolectotype P! P00439335). Fig. 3D.

Whitfieldia gilletii De Wild. (De Wildeman 1905: 316); Durand \& Durand (1909: 421) Type: D. R. Congo, environs de Leopoldville [Kinshasa], fl. Aug. 1902, Gillet s.n. (holotype BR! BR0000008512413).

Whitfieldia brazzei sensu Clarke (1899: 67), pro parte quoad Thollon 210, non (Baill.) C.B.Clarke sensu stricto.

For a description of this species see Evrard \& Demillecamps (1992: 96) while considering note (2) below.

DISTRIBUTION. Whitfieldia thollonii is found in Congo Republic and D. R. Congo (Map 10).

ADDITIONAL COLLECTIONS STUDIED. CONGO REPUBLIC. Bois de Linzolo, fl. 1883, Thollon 210 (P! P00439334, P00439335); au bord du Djoue: fl. May 1888, Thollon 970 (P! P03032888) \& fl. April 1891, Thollon 4053 (K!, P! P03032890, P03032891, P03032892); Kibossi, fl. 20 


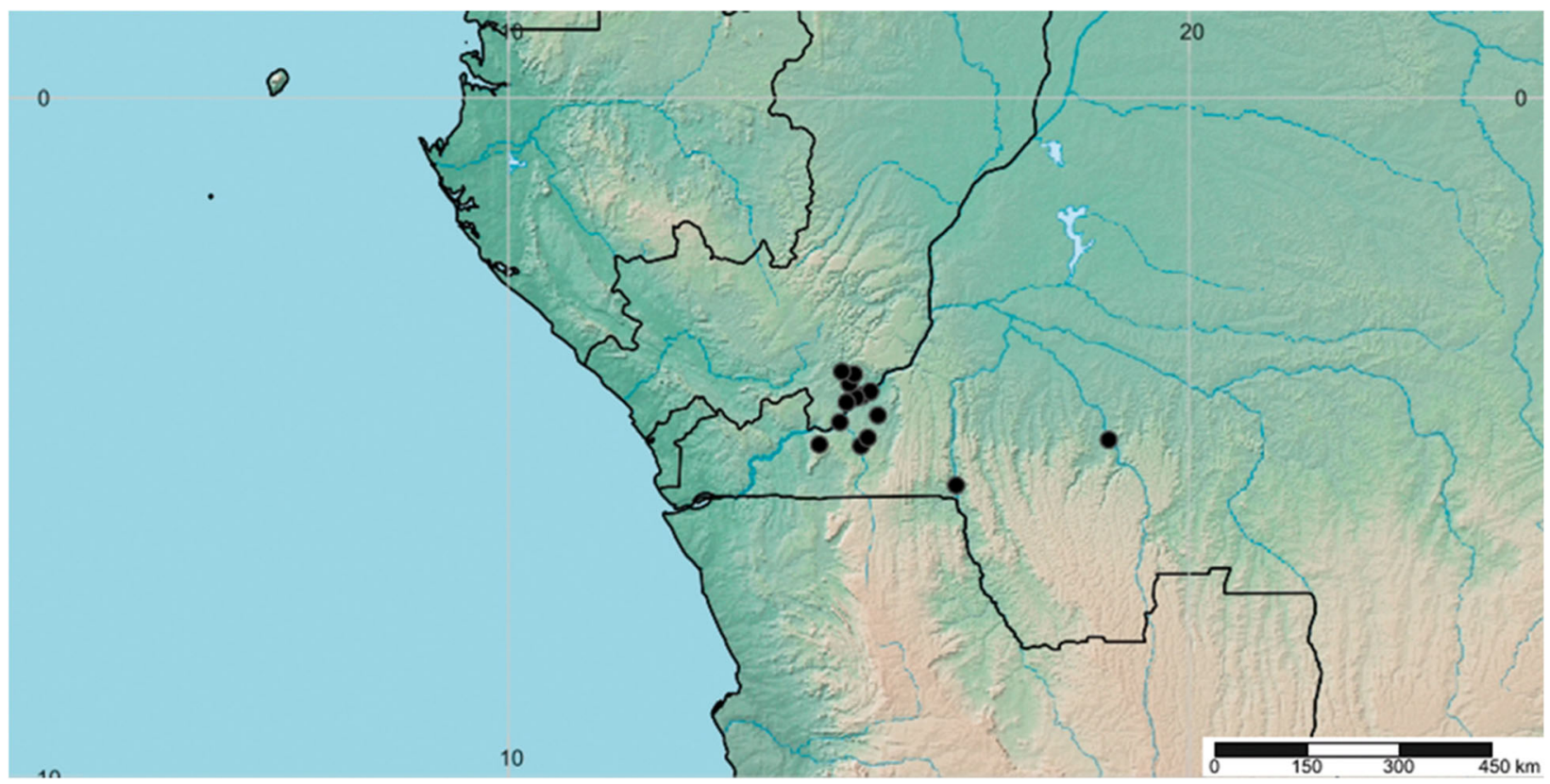

Map 10. Distribution of Whitfieldia thollonii in Congo republic and D. R. Congo.

March 1950, Koechlin 857 (P! P03032883); Route de Mayama, fl. 12 Feb. 1954, Koechlin 4655 (P! P03032887); Route de la Foulakari le long de la Loufini, fr. 5 Aug. 1964, Bouquet 499 (P! P03032884 \& P03032885). D. R. Congo. Sanda, fl. 1903, Oddon 3339 (BR* BR0000008513076) \& Oddon 3754 (BR* BR0000013109301); Sanda, fl. May 1915, Vanderyst 5467 (BR* BR0000013109356); Litendele, fl. June 1916, Achten 482A (BR* BR0000008511751) \& Achten 482B (BR* BR0000008512086); Kimayala, fl. April 1925, Vanderyst 14681 (BR* BR0000013109271) \& Vanderyst 14682 (BR* BR0000013109332 \& BR0000013109333); Goa, fl. 1926, Vanderyst 19104 (BR! BR0000013101664); Wutu a Kipako, fl. May 1932, Vanderyst 30515 (BR* BR0000008509918); Insiki, fr. 19 July 1953, Callens 4164 (BR* BR0000008512741, WAG* WAG0160819); route Zundu-Timansi avant la riviere Mpioka, fl. 21 May 1975, Breyne 2500 (BR* BR0000008517524); Kikwit, fl. 10 Aug. 1991, Masens 870 (BR* BR0000013109240).

HABITAT AND ECOLOGY. Whitfieldia thollonii is recorded from forests, often alongside rivers, but also in palm plantations. The altitude range was not recorded on specimen labels and our knowledge on the ecology of this species is limited.

CONSERVATION STATUS. With all the populations considered, we calculate an EOO of $44,635 \mathrm{~km}^{2}$ and between 12 and 15 locations known historically. However, there is a distinct smaller core range (EOO $=7,553 \mathrm{~km}^{2}$ ) in the vicinity of the two capital cities, Brazzaville and Kinshasa. The collections from there are rather old with the last one from 1975. It is possible that due to deforestation and urban expansion, those locations do not exist anymore today, at least halving the number of locations. The AOO in this core range is only $48 \mathrm{~km}^{2}$, but total AOO is potentially a lot larger for this species as we also need to consider the two outlier locations in Kikwik and Goa in the east. No recent collections of this species have been made so our knowledge on the current population is only estimated. To apply a precautionary approach, we assess it as Vulnerable VU B2 ab(i,ii,iii,v) due to the high level of threat in the core of the range and the assumption that fewer than 10 locations are extant. However, the extinction risk would be reduced if further subpopulations are found within its EOO and away from the large conurbations of Brazzaville and Kinshasa.

NOTES. (1) Previously, this species was considered to be also found in Gabon (Heine 1966), based solely on the collection Le Testu 7255 from Lastoursville. We believe that this collection is actually referable to Whitfieldia purpurata (see Note 2 under W. purpurata above).

(2) Previous authors have noted that it is difficult to separate Whitfieldia thollonii from W. brazzae (Heine 1966: 42; Evrard \& Demillecamps 1992: 96). However, Evrard \& Demillecamps distinguished these species on the basis of the 10 following characters: a) corolla length; b) corolla length/width ratio; c) bracteole shape; d) density of glands on the calyx; e) colour of the corolla; f) leaf shape; g) position of the calyx in the bracteoles; $h$ ) pilosity of the inner corolla; i) pedicel length; and j) pollen morphology. Below, we consider these characters in turn.

(a) According to Evrard \& Demillecamps (1992), the corolla length of Whitfieldia brazzae can reach 
$33 \mathrm{~mm}$ while $W$. thollonii can reach $34 \mathrm{~mm}$ but no range of measurements were given. From our observations, there is no significant difference in corolla length between the two species. (b) We were equally unconvinced by the argument that the length/width ratio $(\mathrm{l} / \mathrm{w})$ of the corollas differs in these taxa, as several specimens identified as W. thollonii by Evrard \& Demillecamps have a $1 / \mathrm{w}$ ratio which is higher than the supposedly maximum of 2.6 (e.g. Oddon 3754 , Achten 482A), and so within the ratio range that they give for W. brazzae. (c) De Wildeman (1905: 317) and Heine (1966) agreed that W. thollonii and its synonym $W$. gilletii have elliptic bracteoles while W. brazzae and its synonym $W$. sylvatica have ovate bracteoles, whilst Evrard \& Demillecamps (1992) argue it is the exact opposite. This disagreement could be explained by different definitions of those shapes by the authors. However, we looked at all specimens cited by those authors, as well as additional material, and we have seen significant variation in the shape of bracteoles ranging from elliptic to ovate with several intermediates, hence not resolving into two well-defined taxa. These differences in bracteole shape are also sometimes visible on a single collection, including on the type specimen for W. brazzae, De Brazza 165, which has both ovate and elliptic bracteoles. (d) In Evrard \& Demillecamps (1992: 96), both species are described as having "a calyx covered with very small white glands" and no difference in the density of glands has been observed by us. (e) The colour of the corolla for W. brazzae is described as brown-yellow by Evrard \& Demillecamps (1992) but a specimen they cited under that species (Compère 1919) was described on the specimen label as pink when fresh and shows clear purple lines when dry. Several specimens from $\mathrm{P}$ identified as $W$. brazzae have flowers which are orange (Farron 5113) or salmon red (Pobéguin 239). For W. thollonii, many labels do not indicate the colour of the fresh corolla. However, purple-brown streaks are present on corollas of all dried specimens of W. thollonii. Moreover, flower buds for this species tend to show dark purple lobes. Hence, even though the corolla colour for both species is more variable than has previously been described, we agree that dark stripes and dark lobes on the corollas are a good indicator of W. thollonii; W. brazzae can show stripes but they are faint and regular. (f) For these two species, as in most Whitfieldia species, the leaves are variable in size and shape within a species and consequently their measurements cannot be used for identification (the exceptions being $W$. rutilans, where the leaves are exceptionally large [see Fig. 3B], and W. purpurata where the leaves are distinctly cuspidate). (g) We did not find a significant difference in the position of the calyx: both taxa can have calyces which are either exserted from or hidden within the bracteoles. This is due partly to variation in the shape of the bracteoles, which can be markedly acuminate hence covering the calyx lobes, and partly to the maturity of the calyx as it continues to grow post-anthesis. (h) Even though the inner corolla of $W$. thollonii is said by Evrard \& Demillecamps (1992) to be pilose, we found several specimens (e.g. Gillet s.n. 1903 \& 1904) for which it is glabrous as in $W$. brazzae. (i) There is a clear difference in pedicel length when the types of W. brazzae (18$25 \mathrm{~mm}$ long) and W. thollonii (4 - $13 \mathrm{~mm}$ long) are compared. However, when all specimens are considered together, this character also loses its strength and appears to be clinal. This is illustrated by the specimens Oddon 3554, Achten 482A and Achten 482B from D. R. Congo, which have unusually long pedicels for W. thollonii (respectively up to $20 \mathrm{~mm}, 17.5 \mathrm{~mm}$ and $25 \mathrm{~mm}$ long).(j) Only minute differences were found in the pollen of $W$. thollonii and W. brazzae as published by Evrard \& Demillecamps (1992). The addition of the photograph of pollen from another specimen of W. brazzei (Fidao s.n.) during this study confirmed the similarities.

In conclusion, then, many of the characters previously used to separate Whitfieldia thollonii from $W$. brazzae do not hold up when the full range of material is examined and only corolla colour appears to differ consistently between the two. However, whereas $W$. brazzae has been collected multiple times both at the border between southwestern Gabon and Congo Republic and in the Brazzaville-Kinshasa area, $W$. thollonii seems much more confined to the second location only. More field observations and photographs are needed to understand at what rank these taxa should be separated. Only photographs of $W$. brazzae have been seen by the authors (see Fig. $3 \mathrm{E}$ ), and photographs of $W$. thollonii would enable us to verify if other characters, such as the orientation of the corolla lobes, help distinguish these two taxa better. Additional studies might reveal these species to be better treated as only infraspecifically distinct.

11. Whitfieldia brazzae (Baill.) C.B.Clarke (1899: 67) as W. brazzei, pro parte, excl. syn. W. thollonii et Thollon 210; Heine (1966: 42); Evrard \& Demillecamps (1992: 93); Walters et al. (2011: 425) 三 Stylarthropus brazzae Baill. (Baillon 1890a: 283), as S. brazzei; Lindau (1895: 306). Type: Congo Republic, bois d'Osika, fl. June 1883, de Brazza 165 (lectotype P P00439320!, selected here; isolectotypes P! P00439321 \& P00439322). Fig. 3E.

Stylarthropus tenuiflora Baill. (Baillon 1890a: 283); Lindau (1895: 306). Type: Congo Republic, dans les bois de Linzolo, fl. May 1885, de Brazza 209 (holotype P P00439323!).

Whitfieldia sylvatica de Wild. (De Wildeman 1905:

317). Type: D. R. Congo, Kimuenza, fl. May 1901 , Gillet 2195 (lectotype BR* 
BR0000009858947, selected here; isolectotype BR* BR0000008515964). Additional syntype: environs de Léopoldville, fl. Aug. 1902, Gillet s.n. (BR* BR0000013396848)

For a description of this species see Evrard \& Demillecamps (1992: 93) while considering note (2) of Whitfieldia thollonii.

DISTRIBUTION. Whitfieldia brazzae is found in Gabon, Congo Republic and D. R. Congo (Map 11). It is also very likely to occur in the Central African Republic (see Note 2).

ADDITIONAL COLLECTIONS STUDIED. GABON. Leconi road at Souba, fl. 21 June 1989, Louis 3107 (LBV, WAG* WAG.1237229); Plateaux Bateke, fl. 8 March 2003, Niangadouma E Walters 217 (LBV, MO, K!); Plateaux Bateke, Kalahari sands, Okeli Forest, fl. 6 Oct. 2003, Walters E Moussavou 1379 (LBV, MO, WAG* WAG.1237226, BR* BR0000005086061); Plateaux Bateke, Mpassa riparian forest, fl. 30 Jan. 2004, Niangadouma 407 (LBV, MO, WAG* WAG.1584056, WAG* WAG.1237416); Haut-Ogoue, Ekouyi village, Okeli forest, fl. 18 July 2006, Walter 1819A (LBV, MO, WAG* WAG.1237228); Plateaux Bateke, Bai Djobo, fl. 10 Sept. 2006, Nguema 786 (LBV, MO, WAG* WAG.1237227); CONGO REPUBLIC. Forêt de BaikiOubangui et Boganga, confluent de l'Oubangui et du Congo, fl. Dec. 1916, Fidao s.n. (K!, P! P03590298); Moyen Congo, rives du Congo, fl. March 1920, Pobéguin 239 (P! P03590299, P03590300) ; Rive gauche de la Foulakari, fl. 3 Aug. 1964, Bouquet 360 (P! P03590303); Plateau des cataractes, route Kinkala-Hamon, forêt de Ngamikole près du village Dzeba, fl. 8 Sept. 1964, Sita
1072 (P! P03590293); Forêt de la Djoumouna, fl. 14 April 1966, Farron 5113 (P! P03590295, P03590296, P03590297, P03590301); Village de Mbese, terre Ongondza sous prefecture de Boundji, fl. 23 June 1965, Bouquet 1460 (P! P03590302, P03590304); Kebara, fl. 1 July 1982, Audru 6710 (P! P03564730); Forêt de la Djoumouna, 25 km W Brazzaville, fl. 12 July 1985, Cusset 1348 (P! P03071790); on the road to Lefoutou airport and Placongo, fl. 25 June 2011, Mampouya 128 (IEC, K! K001400005, P! P00948924); N of Lebayi, fl. 31 May 2010, Kami 5290 (IEC, K! K000678781); sine loc., s.d., Thollon s.n. (P! P03590294); D.R. CONGO. Kimuenza, fl. May 1901, Gillet 2195 (BR* BR0000008515964 \& BR0000009858947); Leopoldville, fl. Aug. 1909, Claessens 35 (BR* BR0000013396800); Sanda, fl. 15 June 1915, Vanderyst 5553 (BR* BR0000013398989); M pese, 1919 , Vanderyst 7614 ( B R* BR0000013399023); dans le Benga, fl. June 1925, Vanderyst 14934 (BR* BR0000013399061); Kinkoko, fl. 20 April 1960, Compere 1919 (BR* BR0000008392916); Manenga, terr. Ngafula, fl. 14 July 1977, Pauwels 5850 (WAG* WAG0160820, BR* BR0000013396923); Milu, zone Maluku, fl. 15 May 1982, Breyne 4296 (BR* BR0000013396763).

HABITAT AND ECOLOGY. Whitfieldia brazzae is found in primary forest and mature secondary forest, often along rivers, at $400-600 \mathrm{~m}$ a.s.l.

CONSERVATION STATUS. This species is known from many collecting sites and has an EOO of 250,399 $\mathrm{km}^{2}$. Several historical collections are from the now heavily degraded Kinshasa-Brazzaville area, where the species is likely to have declined significantly. However, there are still a number of more intact areas where is has been collected. It is protected in the National Park of

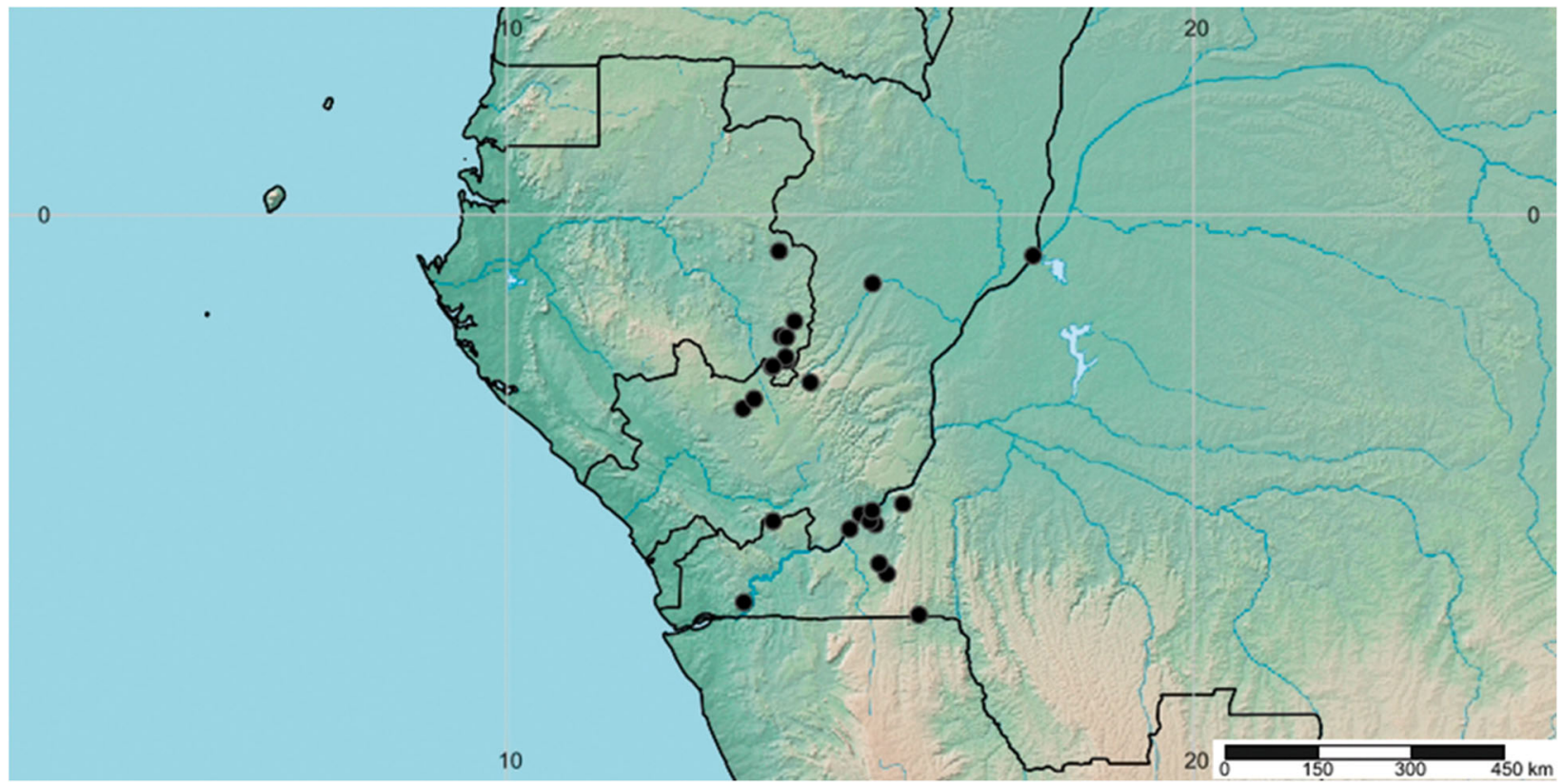

Map 11. Distribution of Whitfieldia brazzae in Gabon, Congo Republic and D. R. Congo. 
the Batéké Plateaux (Protected Planet 2020), where it has been collected several times, including in the last fifteen years. It is therefore considered to be of Least Concern (LC). However, it would be useful to gather more details on current population size, trends and threats. It would be interesting, for example, to assess this species under the criteria $\mathrm{A}$ once we have more information on the current rate of decline.

NOTES. (1) Baillon (1890b: 823) and Clarke (1899: 67) have spelt the epithet "brazzei", the genitive form of "brazzeus". However, this does not follow the established rules of Latin grammar for botanical nomenclature. Since the species has been named after Pierre Savorgnan de Brazza, the correct epithet should be "brazzae" (Heine 1966; Turland et al. 2018, Articles 60.8 and 60.9 ).

(2) Whitfieldia brazzae is very likely present in the Central African Republic and some specimens (e.g. Fidao s.n.) have been collected very close to the Congolese border with that country. However, no specimen from that country has been seen by the authors so far.

(3) For separation from the closely allied Whitfieldia thollonii, see the Notes section under that species.

12. Whitfieldia lateritia Hook. (Hooker 1845: 4155); Clarke (1899: 67); Aké Assi (1961: 199; 1984: 32); Adjanohoun \& Guillaumet (1961: 84); Gledhill (1962: 29); Heine (1963: 398); Adam (1975: 1464); Hawthorne \& Jongkind (2006: 448); Lisowski (2009: 39); Marshall \& Hawthorne (2013: 3, 26). Type: Sierra Leone, sine loc., s.d., Whitfield s.n. (lectotype K! K000394216, selected here; isolectotype K! K000394219). Fig. 3F - G.

Asystasia amoena Turrill (1920: 26), synon. nov. Type: Sierra Leone: round York Pass, fl. \& fr. 10 Jan. 1914, Lane-Poole 180 (K! K000394215).

For a description of this species see Adam (1975: 1464).

DISTRIBUTION. Whitfieldia lateritia is known from West Africa in Guinea, Sierra Leone, Liberia and Ivory Coast (Map 12).

SELECTED COLLECTIONS STUDIED. GUINEA. route Kankan - Macenta, fl. 1 Jan. 1949, Adam 2960 (K! K000865123, PRE!); Macenta prefecture, Simandou range, Banko forest, along the stream near the old Conservation International campsite, fl. 9 Nov. 2005, Tchiengue 2326 (HNG, K! K000436319, MO, P! P03421016); Macenta prefecture, Mts Ziama, N of Seredou on road to Macenta, zone Zobroma, Neolemonniera hill, fl. 22 Oct. 2008, Fofana 150 (HNG, K! K000615127); Coyah prefecture, near Kouriya, near road from Coyah to Kindia, fl. 11 Oct. 2016, Goman 349 (K! K001243785);
Kindia prefecture, forested canyon to Plateau de Tassing above Fossikouré Village, fl. 8 Dec. 2017, van der Burgt 2184 (HNG, K! K001286446, P, WAG* WAG.1970626). SIERRA LEONE: Yonibana, fl. 30 Dec. 1914, Thomas 4018 (K!); York Pass, fl. Dec. 1922, Dawe 406 (K!); Jagba hill, N side, fl. 8 Sept. 1958, Melville $\mathcal{E}$ Hooker 631 (K!); Tonkolili distr., Southern Sula Mts, E of village Farangbaya near Bumbuna, road to Simbili proposed iron ore pit, downstream of the bridge, fl. 27 Nov. 2009, Tonkolili Plants 520 (K! K000023633, SL); Gola National Park, central block, fl. 25 Oct. 2013, Sesay 98 (HNG, K! K001061894, SL, WAG* WAG.1962815). LIBERIA. Gbanga, fl. 8 Sept. 1926, Linder 440 (K!); Eastern province, Tappita distr., fl. 15 Aug. 1947, Baldwin 9031 (K!); Sanokwele distr., Zolopla, fl. 21 Sept. 1947, Baldwin 9390 (K!); Lamco Hq. Camp, fl. 13 Oct. 1964, Adames 651 (K!, P! P03032940); Nimba, near Mt Tokadeh, fl. 12 Nov. 2007, Jongkind 7984 (K!, WAG* WAG0280090 \& WAG0280091, P!, SL). IVORY COAST. Man, fl. Sept. Oct. 1930, Chevalier 34190 (P! P03564090); Adiopoumé, réserve botanique, fl. Jan. 1969, Bamps 1849 (K!); Mont Toukoui, fl. 7 Dec. 1973, Aké Assi 12243 (P! P 03032932 \& P03032933); Forêt de Tiapleu, c. $30 \mathrm{~km}$ N of Danané, fl. 30 Jan. 1984, Hepper Ev Maley 7906 (K!); Man, fl. 13 Oct. 2001, Nusbaumer LN782 (G, P! P04422452).

HABITAT AND ECOLOGY. Whitfieldia lateritia is found in disturbed and undisturbed forest, especially near streams, in gullies or canyons, between 190 and 1010 $\mathrm{m}$ a.s.l.

CONSERVATION STATUS. This species has a large EOO of $174,821 \mathrm{~km}^{2}$ and is known from many collecting sites. It has been collected frequently and it is still today fairly common in suitable forest habitats. According to the notes of past collectors, it also tolerates some disturbance. Nevertheless, it is likely to be declining due to forest loss, although not to such an extent that it would qualify under any of the IUCN threat criteria. This species is therefore assessed as of Least Concern (LC).

NOTE. Whitfieldia lateritia is a rather frequently encountered species in surviving forest of Upper Guinea which shows a continuous variation of colour tones in the bracteoles, calyx (green to red) and corolla (from pale orange, brick-coloured, to pink or red, with or without stripes, sometimes dots, see Fig. 3F). A wide and continuous range of bracteole form has also been observed across its range, varying from broadly ovate to lanceolate or suborbicular, with or without an acumen. Moreover, their width ranges from 5 - 12 $\mathrm{mm}$, a rather wide range compared to other species in the genus. The indumentum on the floral parts also varies, with the bracteoles ranging from almost glabrous to pubescent. However, the stem and the pedicels are always villose with multicellular hairs, 


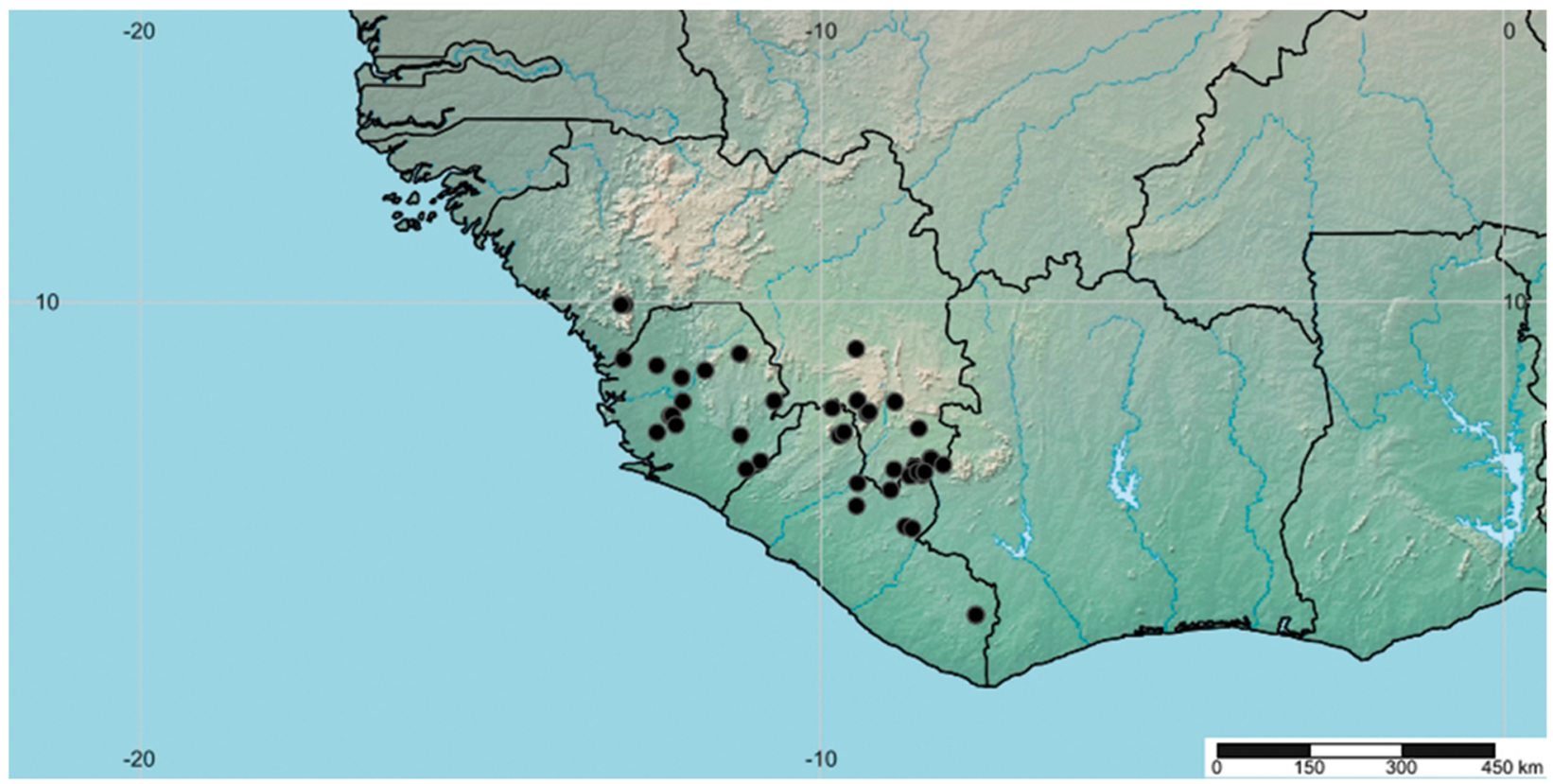

Map 12. Distribution of Whitfieldia lateritia in Guinea, Sierra Leone, Liberia and Ivory Coast.

which facilitates its distinction from W. colorata (glabrous to puberulous) within its distribution range, and from the similar W. brazzae (glabrous) in Gabon and the Congos, where W. lateritia does not occur.

13. Whitfieldia colorata C.B.Clarke ex Stapf (1906: 640); Cooper \& Record (1931: 117); Gledhill (1962: 29); Heine (1963: 399); Adam (1975: 1464); Aké Assi (1984: 32); Bakayoko et al. (2004: 220); Poorter (2004: 385);
Hawthorne \& Jongkind (2006: 448 - 449). Type: Liberia, within 20 miles of Kakatown [Kakata], fl., 1904, Whyte s.n. (lectotype K! K000041544, selected here; isolectotypes K! K000041543, K000394213 \& K001400070, P! P00439324). Fig. 3H - K.

NOTE FOR SPECIES. Whitfieldia colorata is a rather variable species. Two near-allopatric subspecies are recognised here for the first time:

\section{Key to infraspecific taxa of Whitfieldia colorata}

Corolla when fresh pink to copper externally with darker regular stripes and no spots, yellow to green internally; corolla in dry state dusky purple with regular darker stripes; calyx salmon pink to bronze-red; l:w ratio of corolla $3.8-4.4: 1 \ldots \ldots \ldots \ldots \ldots \ldots \ldots \ldots \ldots \ldots$ colorata

Corolla when fresh yellow to green externally with diffuse dark purple to dark brown stripes, sometimes spots internally, green internally; corolla in dry state dirty yellow with irregular stripes; calyx green; l:w ratio of corolla $(3-) 3.5-3.7: 1 \ldots \ldots \ldots \ldots \ldots \ldots \ldots \ldots \ldots \ldots \ldots \ldots \ldots \ldots \ldots \ldots \ldots \ldots$ tigrina

13a. Whitfieldia colorata C.B.Clarke ex Stapf subsp. colorata. Fig. $3 \mathrm{H}-\mathrm{J}$.

For this subspecies see a comparative description in Adam (1975: 1464).

DISTRIBUTION. Subsp. colorata is found in the south of Sierra Leone, and in the southwest and the southern coast of Liberia. It is likely to occur in the Nimba Mountains in Guinea as well, as noted by Adam (1975: 1464), but no specimen has been seen from there by the authors.
ADDITIONAL COLLECTIONS STUDIED. LIBERIA. Within 6 miles of Monrovia, fr. 4 Jan. 1905, Whyte s.n. (K! K000041549); Urwaldreste zur Cap Mesurado, Monrovia, fl. 20 Jan. 1924, Dinklage 2956 (P! P03590290); along Dukwai [Dukwia] R., Monrovia, fl. Oct. Nov. 1928, Cooper 34 (K! K000041546), Dukwia R., fr. 4 Feb. 1929, Cooper 152 (K!); sine loc., fl. 1 Jan. 1935, Dinklage 3355 (BM!, BR* BR0000020157845); banks of Farmington R., fl. 23 Dec. 1943, Bequaert 10 (K! K000041545); Central Province, Salala Distr.: Piatah, fl. 2 Dec. 1947, Baldwin 10611 (K!); Western Province, Boporo Distr.: Ba, on Mano R., near border of Grand 


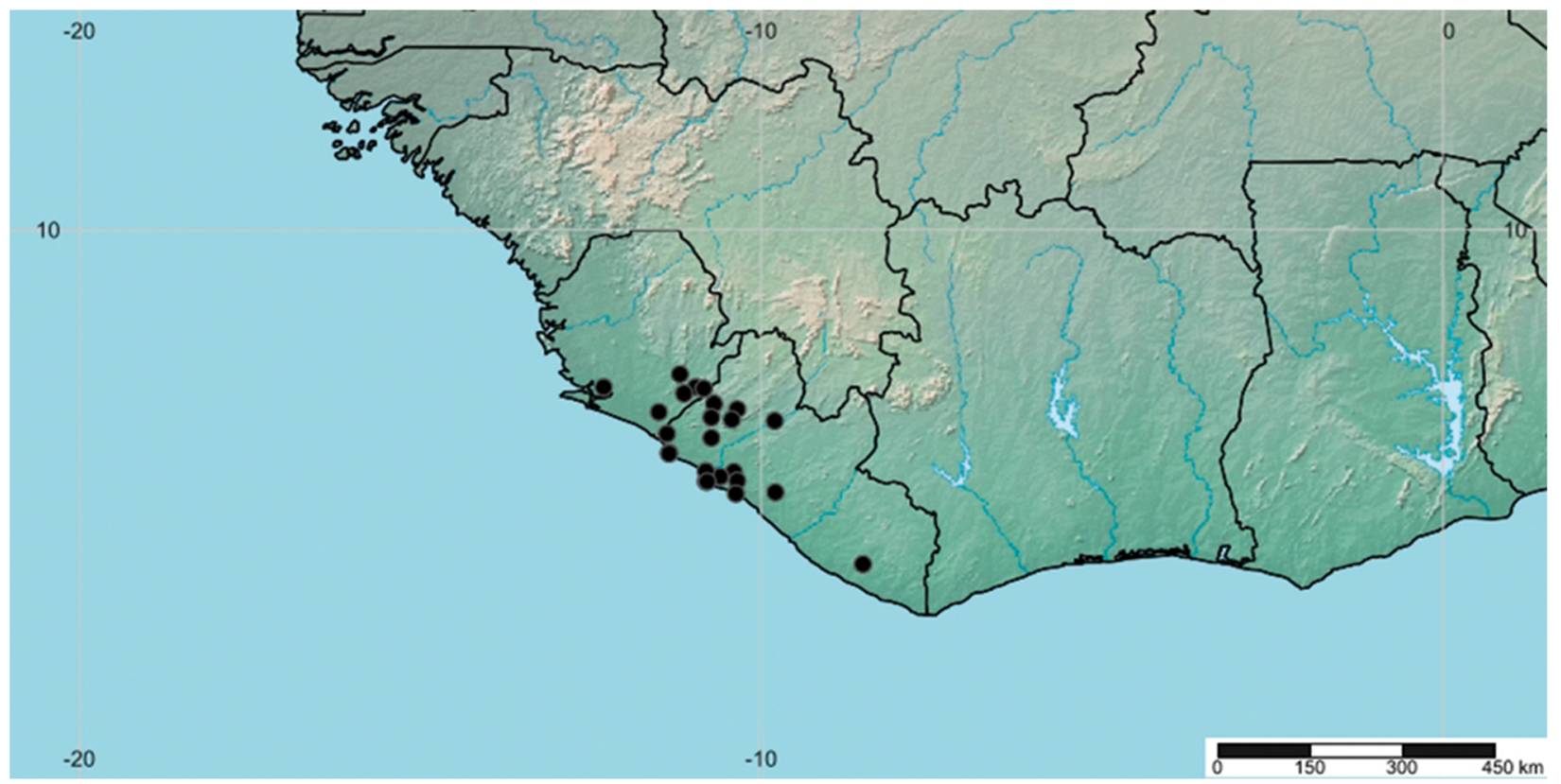

Map 13. Distribution of Whitfieldia colorata subsp. colorata in Sierra Leone and Liberia.

Cape Mount Co., fl. 18 Dec. 1947, Baldwin 10700 (K! K000041550); Grand Cape Mount Co.: Genna Tanyehun, fl. 20 Dec. 1947, Baldwin 10773 (K! K000041551); Blazie, fl. 27 Nov. 1958, Adam 16182 (P! P03590288); Zoka town, fl. 1 Dec. 1958, Adam 19248 (P! P03590292); Toué-Tié-Tié, fl. 9 Dec. 1958, Adam 16319 (P! P03590289); New University site, \pm $35 \mathrm{~km}$ from Monrovia, fl. 2 Jan. 1964, Harten 228 (K!, WAG* WAG0015130); Gola National Park, E of Bomi hills, access road to school forest, fl. 9 Dec. 1966, Bos 2315 (WAG* WAG0015125, WAG0015126); Grand Gedeh, Putuh road, S of Zwedru (Chien, in dark high forest), fr. 18 Jan. 1967, Bos 2872 (WAG* WAG0015128, WAG0015127); 4 miles S of Kakata, 6 miles to W, along road, fl. 7 Nov. 1968, Jansen 1015 (BR* BR0000020157852, P! P03590291); 10 miles from Tchien, along the road to Cape Palmas, fl. \& fr. 22 Jan. 1969, Jansen 1298 (K!, WAG* WAG0160524, WAG0015122); 20 miles $\mathrm{W}$ of Bomi Hills, road to Mano, fl. 12 Feb. 1969, Jansen 1494 (BR* BR0000020157869, WAG* WAG0015120); about 10 miles N of Monrovia, Savanna area, fl. 19 Feb. 1969, Jansen 1602 (WAG* WAG0015124); 3 miles $\mathrm{N}$ of settlement of MMAL mine company, fl. 12 Feb. 1970, Jansen 1799 (K!, WAG* WAG0015121); Montserrado, 8 miles N of Bomi hills, fl. 28 Jan. 1971, Goll 68 (WAG* WAG0093391); Grand Cape Mount, c. 5 miles E of Robertsport in hilly country, fl. 12 Jan. 1978, Gier 127 (BR* BR0000020157876, WAG* WAG0093372); Lofa, road from Bopolu to kpelle Nat. Forest, about 15 miles E of Bopolu, fl. 19 Jan. 1978, Gier 227 (WAG* WAG0093322); Montserrado, Old Porrobush on Bentol Road, about 5 miles before Bentol, fl. \& fr. 9
Feb. 1978, Gier 248 (WAG* WAG0093345); Grand Gedeh, along Zwedru-Harper road, south of Tiama Town, fl. 7 June 2005, Jongkind 6663 (WAG* WAG0124407); Grand Cape Mount, Gola Forest, fl. 28 Nov. 2005, Jongkind 6927 (BR* BR0000020157906, WAG* WAG0221569, WAG0221568); Gbarpolu, Kpelle Forest, N of Gainkpa, fl. 13 Dec. 2010, Jongkind 10102 (BR* BR0000020157920, K! K001400225, WAG* WAG0409410); Grand Cape Mount, Cape Mount, fr. March 2013, Jongkind 11787 (BR* BR0000014275708, WAG* WAG.1487950); Dugbe Hummingbird site (c. $20 \mathrm{~km} \mathrm{~S}$ of Sapo National Park, c. $50 \mathrm{~km} \mathrm{E}$ of Greenville), near Tuzon, along the Geebo R., fl. 24 Dec. 2013, Senterre 6948 (BRLU* BRLU0018690). SIERRA LEONE. Jepihun, fl. Dec. 1907, Smythe 228 (K! K000041568); Pujehun, fl., 1915, Thomas 8663 (K! K000041572): Kenema, fl., 1915, Thomas 7967 (K! K000041570); Falaba, fl., s.d., Burbridge 471 (K! K000041569); Giewahun, fl. 20 Nov. 1926, Deighton 363 (K! K000041573); le Gaura chiefdem, near Lalahun, fl. 29 Dec. 1950, King 196B (K! K000041574); Gola Forest, fl. 19 March 1952, Small 548 (K! K000041575); le Gbanbama, fl., s.d., Thomas 9014 (K! K000041571).

HABITAT AND ECOLOGY. Whitfieldia colorata subsp. colorata is a scandent shrub found in moderate shade in primary and secondary forest. It grows from sea level to $140 \mathrm{~m}$ a.s.l.

CONSERVATION STATUS. This subspecies has an EOO of $55,521 \mathrm{~km}^{2}$ and occurs at many collecting sites. Some coastal sites where historical collections have been made (such as near Kakata) are currently facing significant loss of forest habitat, in the Gola National Park, where the plant was collected in the last twenty 
years, the Bomi Hills are also targets for open cast iron ore mining (Gunn et al. 2018). However, the subspecies is also present in areas of good intact forests within the Gola National Parks in both Sierra Leone and Liberia. Consequently, it is assessed as of Least Concern (LC).

13b. Whitfieldia colorata subsp. tigrina A.Grall $\mathcal{E}$ I.Darbysh. subsp. nov. Type: Liberia, Sino, Sapo National Park, fl. 31 Jan. 2010, Jongkind 9339 (holotype K! K001400329 isotypes BR! BR0000020157883, COI* COI00092472, E, MA, MO, P! P00886037, WAG* WAG0245449). Fig. 3K.

http:/ /www.ipni.org/urn:lsid:ipni.org:names:77216479-1

RECOGNITION. This subspecies differs from subsp. colorata in the corolla being green to yellow with red to dark purple stripes slightly blurred towards the lobes (vs pink to red corolla with more regular and darker red veins that are neat up to the lobes); in the calyx being green (vs copper to pink); and in the corollas being generally shorter and proportionally slightly broader, with a l:w ratio (3 -) $3.5-$ 3.7: 1 (vs elongate and proportionally narrower corolla; l:w ratio $3.8-4.4$ : 1 ).

DISTRIBUTION. Whitfieldia colorata subsp. tigrina is recorded from the eastern part of Liberia and western Ivory Coast in the Sassandra region (Map 14).

ADDITIONAL COLLECTIONS STUDIED. LIBERIA. Sinoe Basin, fr. 4 Jan. 1905, Whyte s.n. (K! K000041547); Sino, Sapo National Park, buffer zone, near Sinoe R., fl. 23 Nov. 2002, Jongkind 5183 (WAG* WAG0070318);
Grand Bassa, Cestos-Sanguin area, logging concession of the Cooper's, Sudan section, fl. 6 Dec. 2002, Jongkind 5661 (BR!, BR0000020157913, G* G00351120, WAG* WAG0070620); Grand Gedeh, Grebo Forest, fl. 8 Dec. 2005, Jongkind 7202B (WAG* WAG0221085); Sino, near footpath SW of Jalay's town going to Greenville, fr. 14 March 2009, Jongkind 8977 (WAG* WAG0320734); Sino, SW of Togbaville, fl. 29 Nov. 2010, Jongkind 9902 (BR! BR0000016836761, WAG* WAG0409472); Sino, Sapo National Park, fl. 31 Jan. 2010, Jongkind 9339 (BR! BR0000020157883, P! P00886037, WAG* WAG0245449). IVORY COAST. $56 \mathrm{~km}$ $\mathrm{N}$ of Sassandra, E of Beyo., fl. 17 Dec. 1958, Leeuwenberg 2223 (WAG* WAG0005280); $61 \mathrm{~km} \mathrm{~N}$ of Sassandra, W of Niapidou, fl. 18 Jan. 1959, Leeuwenberg 2475 (WAG* WAG0005279); $61 \mathrm{~km} \mathrm{~N}$ of Sassandra, W of Niapidou, fr. 19 Feb. 1959, Leeuwenberg 2757 (WAG* WAG0005281); entre Bacanda et Tiepo, fl. 13 Jan. 1965, Aké Assi 8442 (G* G00394941); Tabou, road to nearby village near the sea, fl. 12 Oct. 1973, Koning 2434 (WAG* WAG0060346); Sassandra, P.N. de Taï, entre Djiroutou et le Mont Niénoukoué, fl. 3 Feb. 1999, Menzies CC1546 (G* G00394940); Sassandra; Forêt Classée Niégre, E of Keitadougou, fl. \& fr. 23 March 2000, Jongkind 4665 (WAG* WAG0013344, WAG0013345).

CONSERVATION STATUS. This subspecies has an EOO of $31,278 \mathrm{~km}^{2}$ with only 11 locations known. The collections made in Ivory Coast are quite old and there has been significant forest loss in Ivory Coast within its distribution range, mainly due to the development of crops of cocoa, coffee, rubber, bananas, etc. for export, but also slash and burn subsistence agriculture and timber production (Koné

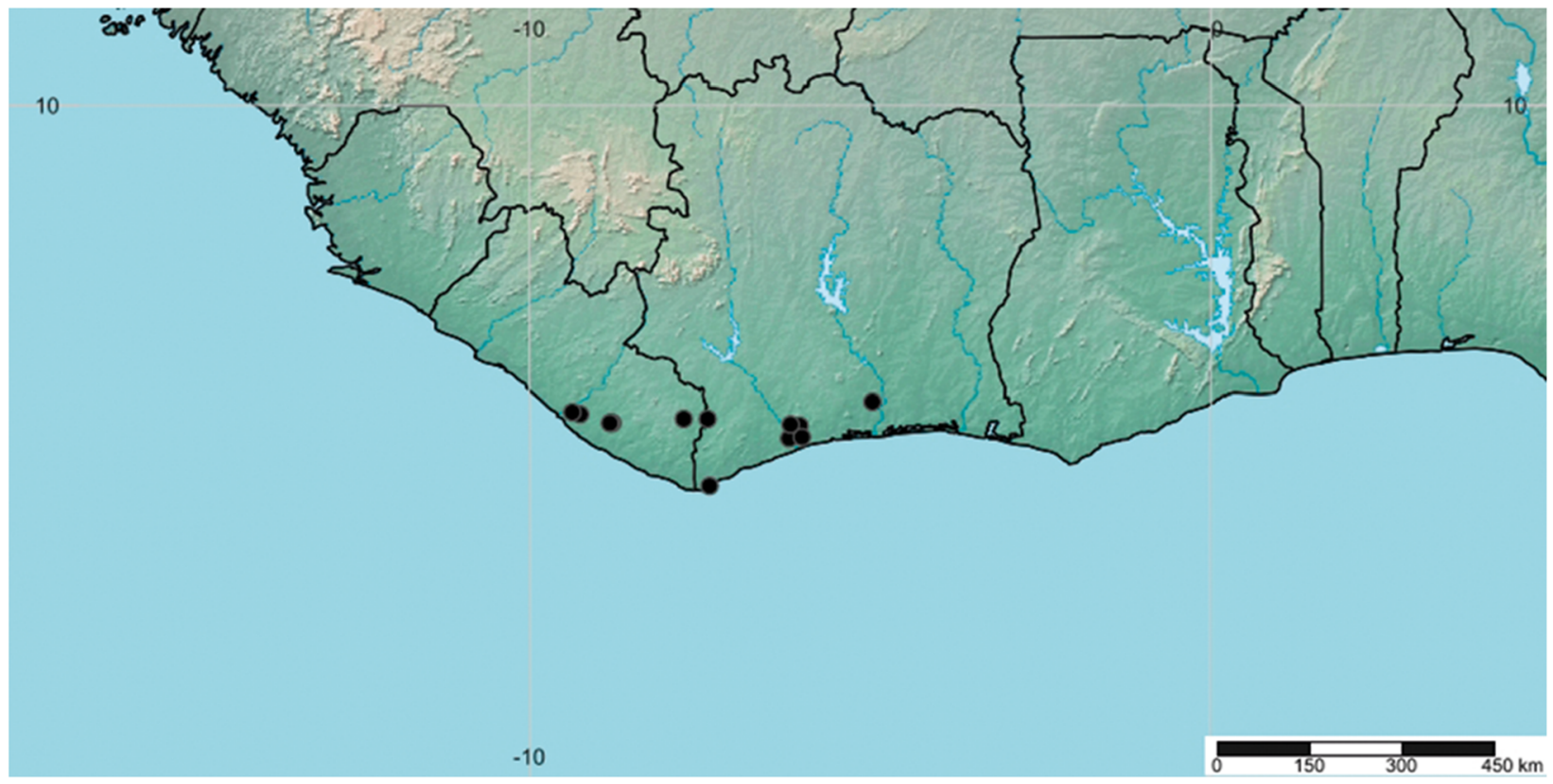

Map 14. Distribution of Whitfieldia colorata subsp. tigrina in Liberia and Ivory Coast. 
et al. 2014). Three specimens were collected in a classified Forest (Forêt de la Niégré: Jongkind 4665; Leeuwenberg $2475 \& 2757$ ), but that area has not been exempt from deforestation since the 1970s and much land in this supposedly protected area has been sold to migrants who converted the forest into cocoa plantations (Eblin et al. 2018). Two more Ivorian collections (Leeuwenberg 2223; Breteler 6063) were made east of the Forêt de la Niégré in the 1950s and the 1960s respectively, and there is now very little forest cover left at that location. Another Ivorian collection was made in Tabou in 1973 (Konning 2434) and the area is now heavily urbanised with little forest remaining, so there is little chance that the location still exists. This subspecies was collected in the Taï Forest in 1999 (Menzies CC1546). However, the Taï National Park, despite its protected status, has suffered from deforestation due to the expansion of cocoa plantation, illegal timber production, slash and burn agriculture and bush fires (Boissieu et al. 2007; Barima et al. 2016). One collection was made between Bacanda and Tiepo [Chiepo] in 1965 (Aké Assi 8442) in the Go Bodiénou Classified Forest. Little is known on the protection of that Forest in the last 50 years, and even though some forest is still visible in the area on Google Earth, with the absence of protection (Protected Planet 2020), one can doubt of the presence of W. colorata subsp. tigrina there today. The locations in the east of Liberia, however, seem much more intact with good forest cover still present. Moreover, several collections were made in the Sapo and Cestos-Senkwhen National Parks where the forest is well protected. This portion of Liberia is also largely under-collected and has good suitable habitat for this taxon, hence it is rather difficult to calculate a precise AOO. To conclude, even though the situation for this species is perilous in Ivory Coast, the east of Liberia is much more promising with national parks and a good forest cover in most of the area where the subspecies can be found. We therefore assess this subspecies as Near Threatened: NT Blab(iii,iv,v).

NOTES. The authors contacted Carel Jongkind in 2018 to ask him if he had seen Whitfieldia latiflos while conducting fieldwork in Liberia. While he had not, he described interesting plants that he had collected from the Ivory Coast/Liberia border area and which did not key out as either $W$. lateritia or $W$. colorata. Those plants were new to us, and thanks to Carel's observations, a careful combination of morphological observations and mapping led us to conclude that three taxa were indeed present in the area. These are here treated as $W$. lateritia, W. colorata subsp. colorata and $W$. colorata subsp. tigrina. The two latter taxa appear much closer to each other (narrow calyx lobes, dense inflorescence) than to $W$. lateritia, particularly in a dry state, hence they were treated as subspecies in this synopsis. However, additional future collections, photographs, and observations at the fruiting stage might lead to a re-evaluation of their rank.

\section{CURRENTLY UNPLACED SPECIMENS OF WHITFIELDIA COLORATA}

The two subspecies cannot be separated at the vegetative or fruiting stage. As a consequence, a few collections with fruits or fallen flowers cannot be assigned to one or the other subspecies with confidence.

One flowering specimen (Voorhoeven 134, WAG) is unusual in its dense inflorescence with rather large bracteoles and could not be identified at the subspecies level; it needs further study.

LIBERIA. Grand Bassa Co.: across Cess R., fl. 9 March 1948, Baldwin 11294 (K!); Bomi Hills, Yoma Distr. of the Gola Nat. Forest, fl. 23 Nov. 1960, Voorhoeve 134 (WAG* WAG0015132); Krahn Bassa Forest, fl. 3 Feb. 1964, van Harten 322 (WAG* WAG0015129); Sino, E of Pelloken village, fr. 5 Feb. 2016, Jongkind 12970 (WAG* WAG.1943740). SIERRA LEONE. Pujehun, fr. Feb. 1915, Thomas 8451 (K!); loc. ibid., Feb. 1915, Thomas 8642 (K!); loc. ibid., Feb. 1915, Thomas 8649 (K!).

\section{Acknowledgements}

The authors thank the curators of the BR herbarium for sending material on loan. We thank the curators Ranee Prakash in BM, Marc Jeanson and Pete Phillipson in P, and Eric N'Gansop in YA for providing us with access to their collections; the curators Geoffrey Fadeur at BRLU and Laurent Gautier at G for sending digital images of herbarium specimens of Whitfieldia; the illustrator Andrew Brown for his illustration of Whitfieldia latiflos; and the botanists and field photographers Xander van der Burgt, Carel Jongkind, Olivier Lachenaud, Nicolas Texier, JeanPierre Vande Weghe and Bart Würsten for allowing us to use their excellent field photographs and for providing their botanical and ecological observations. Discussions with Kaj Vollesen, Isabel Larridon and Heather Lindon at $\mathrm{K}$ were very helpful. We also thank Federico Fabriani at $\mathrm{K}$ for his help with photographing under the binocular microscope and the Kew Africa Team for their support during this research.

Open Access This article is licensed under a Creative Commons Attribution 4.0 International License, which permits use, sharing, adaptation, distribution and reproduction in any medium or format, as long as you give appropriate credit to the original author(s) and the source, provide a link to the Creative Commons licence, and indicate if changes were made. The images or other third party material in this article are included in the article's Creative Commons 
licence, unless indicated otherwise in a credit line to the material. If material is not included in the article's Creative Commons licence and your intended use is not permitted by statutory regulation or exceeds the permitted use, you will need to obtain permission directly from the copyright holder. To view a copy of this licence, visit http://creativecommons.org/ licenses/by/4.0/.

\section{References}

Adam, J. G. (1975). Flore descriptive des Monts Nimba, Part 4. Mém. Mus. Natl. Hist. Nat. sér. II/B 25: $1382-1586$.

Adjanohoun, E. \& Guillaumet, J. L. (1961). Etude botanique entre Bas-Sassandra et Bas-Cavally. ORSTOM, Adiopodoumé.

African Plant Database (2020). African Plant Database (version 3.4.0). Conservatoire et Jardin botaniques de la Ville de Genève and South African National Biodiversity Institute, Pretoria. Available at: http:// www.ville-ge.ch/musinfo/bd/cjb/africa/. [Accessed Jan. 2019].

Agnew, A. D. Q. (2013). Upland Kenya Wild Flowers and Ferns. Third Edition. The East Africa Natural History Society, Nairobi.

Aké Assi, L. (1961). Contribution à l'étude floristique de la Côte d'Ivoire et des territoires limitrophes. Éditions Paul Lechevalier, Paris.

(1984). Flore de la Cote d'Ivoire: étude descriptive et biogéographique, avec quelques notes ethnobotaniques. Thesis, Université d'Abidjan, Ivory Coast.

Anderson, T. (1863). An enumeration of the species of Acanthaceae from the continent of Africa and the adjacent islands. J. Proc. Linn. Soc., Bot. 7: 13 - 53.

Andrews, F. W. (1956). The Flowering Plants of Sudan. Vol. III (Compositae - Gramineae). T. Buncle \& Co., Arbroath.

Bachman, S., Moat, J., Hill, A.W., de la Torre, J. \& Scott, B. (2011). Supporting red list threat assessments with GeoCAT: Geospatial conservation assessment tool. ZooKeys 150: 117 - 126.

Bakayoko, A., Martin, P., Gautier, L., Chatelain, C., Traore, D. \& Spichiger, R. (2004). Étude comparative des massifs forestiers entourant la zone de Taï à Zagné (sud-ouest de la Côte d'Ivoire). Candollea 59 (2): 191 - 229.

Baillon, M. H. (1890a). Histoire des plantes, Vol. 10. Librairie Hachette \& Cie, Paris.

(1890b). Sur plusieurs Acanthacées à fleurs involucrées. Bull. Mens. Soc. Linn. Paris 2 (103): $820-823$.

Barima, Y. S. S., Kouakou, A. T. M., Bamba, I., Sangne, Y. C., Godron, M., Andrieu, J. \& Bogaert, J. (2016). Cocoa crops are destroying the forest reserves of the classified forest of Haut-Sassandra (Ivory Coast). Global Ecol. Conserv. 8: 85 - 98.

Beentje, H. (1994). Kenya Trees, Shrubs and Lianas. National Museums of Kenya, Nairobi.
(2016). The Kew Plant Glossary: an illustrated dictionary of plant terms. Second Edition. Royal Botanic Gardens, Kew.

Benoist, R. (1928). Acanthacées nouvelles du Gabon. Bull. Soc. Bot. France 74: 671 - 673.

(1938). Nouvelles Acanthacées africaines et malgaches. Bull. Soc. Bot. France 85: 678 - 686.

Bloesch, U., Troupin, G. \& Derungs, N. (2009). Les plantes ligneuses du Rwanda: flore, écologie et usage. Shaker Verlag GmbH, Duren.

Boissieu, D. D., Salifou, M., Sinsin, B., Alou, M., Famara, D., Fantodji, A., Fosso, B., Comian Kakpo, M., Ngandjui, G., Obama, C. \& Sagno, C. (2007). La gestion des aires protégées: contexte général dans sept pays d'Afrique de l'Ouest et du Centre [The management of protected areas in seven countries of West and Central Africa]. IRD Editions, Montpellier.

Brenan, J. P. M. (1952). Notes on African Commelinaceae. Kew Bull. 7 (2): 179 - 208.

Brewer, G. E., Clarkson, J. J., Maurin, O., Zuntini, A. R., Barber, V., Bellot, S., Biggs, N., Cowan, R. S., Davies, N. M. J., Dodsworth, S., Edwards, S. L., Eiserhardt, W. L., Epitawalage, N., Frisby, S., Grall, A., Kersey, P. J., Pokorny, L., Leitch, I. J., Forest, F. \& Baker, W. J. (2019). Factors affecting targeted sequencing of 353 nuclear genes from herbarium specimens spanning the diversity of angiosperms. Front. Plant Sci. 10: Art. 1102.

Burgess, N. D. \& Clarke, G. P. (2000). Coastal forests of eastern Africa. IUCN-The World Conservation Union, Publications Services Unit, Cambridge.

Burkill, H. M. (1985). Useful Plants of West Africa, Vol. 1. Royal Botanic Gardens, Kew.

Burrows, J. E., Burrows, S., Lötter, M. \& Schmidt, E. (2018). Trees and Shrubs of Mozambique. Jacana Media, Johannesburg.

Butsic, V., Baumann, M., Shortland, A., Walker, S. \& Kuemmerle, T. (2015). Conservation and conflict in the Democratic Republic of Congo: The impacts of warfare, mining, and protected areas on deforestation. Biol. Conserv. 191: 266 - 273.

Champluvier, D. (1985). Acanthaceae. In: G. Troupin (ed.), Flore du Rwanda, Spermatophytes 3: 422 492, Musée Royal de l'Afrique Centrale, Tervuren.

Cheek, M., Pollard. B. J., Darbyshire, I., Onana, J.-M. \& Wild, C. (2004). The Plants of Kupe, Mwanenguba and the Bakossi Mountains, Cameroon: A conservation checklist. Royal Botanic Gardens, Kew.

, Harvey, Y. \& Onana, J.-M. (2011). The Plants of Mefou Proposed National Park, Yaoundé, Cameroon, A Conservation Checklist. Royal Botanic Gardens, Kew.

Clarke, C. B. (1899). Whitfieldia. In: W. T. ThiseltonDyer (ed.), Flora of Tropical Africa, Vol. 5: 65 - 68. L. Reeve \& Co., London.

(1900). Addenda: Whitfieldia. In: W. T. ThiseltonDyer (ed.), Flora of Tropical Africa, Vol. 5: 511. L. Reeve \& Co., London. 
Cooper, G. P. \& Record, S. J. (1931). The evergreen forests of Liberia: a report on investigations made in the West African Republic of Liberia by the Yale University School of Forestry in cooperation with the Firestone Plantations Company. Bull. Yale Univ. School Forest. 31: 1 - 185.

Dale, I. R. \& Greenway, P. J. (1961). Kenya Trees and Shrubs. Buchanan's Kenya Estates Ltd., Nairobi, in association with Hatchards, London.

Darbyshire, I. (2009). Taxonomic notes and novelties in the genus Isoglossa (Acanthaceae) from east Africa. Kew Bull. 64: 401 - 427.

(2014). Whitfieldia preussii. The IUCN Red List of Threatened Species 2014: e.T45415A3001372. https:// d o i . org / 10.2305 / I U C N. U K . 2014 3.RLTS.T45415A3001372.en. [Accessed 12 Nov. 2019]. , Fisher, A. E., Kiel, C. A. \& McDade, L. A. (2019). Phylogenetic relationships among species of Barleria (Acanthaceae, Lamiales): molecular data reveal complex patterns of morphological evolution and support a revised classification. Taxon 68: $92-111$.

, Kordofani, M., Farag, I., Candiga, R. \& Pickering, H. (2015). The Plants of Sudan and South Sudan. An annotated checklist. Royal Botanic Gardens, Kew.

De Beauvois, P. (1804). Flore d'Oware et de Benin, en Afrique, Vol. 1. Imprimerie de Fain jeune et compagnie, Paris.

De Wildeman, E. A. J. (1905). Études de systématique et de géographie botaniques sur la flore du Bas-et du Moyen-Congo. Ann. Mus. Congo Belge, Bot. Ser. 5 (1), fasc. 3: 213 - 344 .

(1910). Études de systématique et de géographie botaniques sur la flore du Bas et du Moyen Congo. Ann. Mus. Congo Belge, Bot. Sér. 5 (3), fasc. 2: 149 - 320.

(1912). Études de systématique et de géographie botanique sur la flore du Bas et du Moyen Congo. Ann. Mus. Congo Belge, Bot. Sér. 5 (3), fasc. 3: 317 533.

\& Durand, T. (1899). Illustrations de la flore du Congo. Ann. Mus. Congo Belge, Bot. Sér. 1 (1), fasc. 3: $49-72$.

Durand, T. \& De Wildeman, E. A. J. (1899). Materiaux pour la flore du Congo. Bull. Soc. Roy. Bot. Belgique 38 (3): $78-116$.

\& Durand, H. (1909). Sylloge Florae Congolanae(Phanerogamae). Maison Albert De Boeck, Brussels.

Eblin, M. O., Yeo, P. A., Amani, Y. C. \& Yoro, B. M. (2018). Réseaux d'implantation des ressortissants ouest africains dans la foret classée de la Niégré (Sud-Ouest de la Cote d'Ivoire). Rev. Africaine d'Anthropol., Nyansa-Po 27: 192 - 206,

Ensermu Kelbessa (2006). Acanthaceae. In: I. I. Hedberg, Ensermu Kelbessa, S. Edwards, Sebsebe Demissew \& E. Persson (eds), Flora of Ethiopia E Eritrea, Vol. 5: 345 - 495. The
National Herbarium, Addis Ababa University and The Department of Systematic Botany, Uppsala University.

Escourrou, P. (1988). Etude de quelques bioclimats humains d'Afrique tropicale (Some human bioclimates in tropical Africa). Bull. Assoc. Géogr. France 65 (5): 367 - 375.

Evrard, C. M. \& Demillecamps, E. (1992). Etude systématique et palynologique du genre Whitfieldia (Acanthaceae - Whitfieldieae). Belg. J. Bot. 125 (1): 89 100.

Faegri, K. \& Van Der Pijl, L. (2013). Principles of pollination ecology. Third Edition. Elsevier, Amsterdam.

Friedrich, A. (1911). Wissenschaftliche Ergebnisse Der Deutschen Zentral-Africa-Expedition, 1907 - 1908: Unter Führung Adolf Friedrichs, Herzogs Zu Mecklenburg, Vol. 2. Klinkhardt \& Biermann, Leipzig.

Friis, I. \& Vollesen, K. (2005). Flora of the SudanUganda border area east of the Nile: II. Catalogue of vascular plants, 2nd part, vegetation and phytogeography. Biol. Skr. (Biological Series) 51 (2): 391 855.

Furness, C. A. \& Vollesen, K. (1991). The identity of Asystasia striata S. Moore (Acanthaceae). Kew Bull. 46 (4): $729-731$.

Gledhill, D. (1962). Check list of the flowering plants of Sierra Leone. University College of Sierra LeoneDepartment of Botany, Bunumbu Press, Bunumbu.

Gunn, A. G., Dorbor, J. K., Mankelow, J. M., Lusty, P. A. J., Deady, E. A., Shaw, R. A. \& Goodenough, K. M. (2018). A review of the mineral potential of Liberia. Ore Geology Reviews 101: 413 - 431.

Hawthorne, W. D. \& Jongkind, C. C. (2006). Woody plants of Western African forests, a guide to the forest trees, shrubs and lianas from Senegal to Ghana. Royal Botanic Gardens, Kew.

Heine, H. (1963). Acanthaceae. In: J. Hutchinson, J. M. Dalziel, R. W. J. Keay \& N. Hepper (eds), Flora of West Tropical Africa, Vol. 2 (2): 391 - 432. Royal Botanic Gardens, Kew.

(1966). Acanthacées. In: A. Aubréville (ed.), Flore du Gabon, Vol. 13: 1 - 250. Museum National d'Histoire Naturelle, Paris.

Hiern, W. (1900). Catalogue of the African plants collected by Dr Friedrich Welwitsch in 1853 - 61, Vol. 1. British Museum (Natural History), London.

Hooker, W. J. (1845). Whitfieldia lateritia Hook. Curtis's Bot. Mag. 71: t. 4155.

\& Vogel, T. (1849). Niger flora: or, an enumeration of the plants of western tropical Africa, Vol. 1. H. Bailliere, London.

Hutchinson, J. \& Dalziel, J. M. (1931). Acanthaceae. Flora of West Tropical Africa, Vol. 2, Part 1. The Crown Agents for the Colonies, London. 
Iversen, S. T. (1991). The Usambara Mountains, NE Tanzania: phytogeography of the vascular plant flora. Symb. Bot. Upsal. 29 (3): 1 - 234.

IUCN (2012). IUCN Red List Categories and Criteria. Version 3.1. Second Edition. IUCN Species Survival Commission, Gland \& Cambridge.

Jongkind, C. C. H. (2018). Novitates Gabonenses 87: a new Urobotrya from Gabon. Bothalia 48 (1): 1 - 3.

\& Texier, N. (2019). Novitates Gabonenses 92: Combretum rupestre (Combretaceae), a new liana species from Mount Ngouadi in Gabon. Candollea 74: 9 - 14 .

Kiel, C. A., McDade, L. A., Daniel, T. F. \& Champluvier, D. (2006). Phylogenetic delimitation of Isoglossinae (Acanthaceae: Justicieae) and relationships among constituent genera. Taxon 55: 683 - 694 .

, Daniel, T. F. \& McDade, L. A. (2018). Phylogenetics of New World 'justicioids'(Justicieae: Acanthaceae): Major lineages, morphological patterns, and widespread incongruence with classification. Syst. Bot. 43 (2): 459 - 484.

Kimpouni, V. (2008). Premières données sur la diversité floristique de la forêt d'Aubeville (CongoBrazzaville). Syst. Geogr. Pl. 78 (1): 47 - 62.

Koné, M., Kouadio, Y. L., Neuba, D. F., Malan, D. F. \& Coulibaly, L. (2014). Évolution de la couverture forestière de la Côte d'Ivoire des années $1960 \mathrm{au}$ début du 21e siècle/ [evolution of the Forest cover in cote D'ivoire since 1960 to the beginning of the 21st century]. Int. J. Innov. Appl. Stud. 7 (2): 782 - 794.

Lachenaud, O., Stévart, T., Boupoya, A., Texier, N., Dauby, G. \& Bidault, E. (2018). Novitates Gabonenses 88: additions to the flora of Gabon and new records of little-known species. Pl. Ecol. Evol. 151 (3): 393 - 422.

Lebrun, J.-P. \& Stork, A. L. (1997). Énumération des plantes à fleurs d'Afrique Tropicale. Vol. IV. Gamopetales: Clethraceae à Lamiaceae. Conservatoire et Jardin Botaniques, Geneva.

Lejoly, J., Ndjele, L. \& Geerinck, D. (2010). Catalogueflore des plantes vasculaires des districts de Kisangani et de la Tshopo (RD Congo). D.J.P. de Blaay, Durbuy.

Lindau, G. (1894). Acanthaceae africanae II. Bot. Jahrb. Syst. 20: $1-76$.

(1895). Acanthaceae. In: A. Engler \& K. Prantl (eds), Die Natürlichen Pflanzenfamilien nebst ihren Gattungen und wichtigeren Arten, insbesondere den Nutzplanzen, unter Mitwirkung zahlreicher hervorragender Fachgelehrten begründet, T. 4, Abt. 3. W. Engelmann, Leipzig.

(1897). Acanthaceae africanae IV. Bot. Jahrb. Syst. 24: $310-325$.

(1911). Acanthaceae. In: J. Mildbraed (ed.), Wissenschaftliche Ergebnisse der Deutschen ZentralAfrika Expedition 1907 - 1908, Band II. Botanik, pp. 291 - 310. Klinkhardt \& Biermann, Leipzig.
Lisowski, S. (2009). Flore (angiospermes) de la République de Guinée. Jardin Botanique National de Belgique, Meise.

Manktelow, M., McDade, L. A., Oxelman, B., Furness, C. A. \& Balkwill, M. -J. (2001). The enigmatic Tribe Whitfieldieae (Acanthaceae): delimitation and phylogenetic relationships based on molecular and morphological data. Syst. Bot. 26: $104-119$.

Maroyi, A. (2006). Preliminary checklist of introduced and naturalized plants in Zimbabwe. Kirkia 18 (2): 177 - 247.

Marshall, C. A. \& Hawthorne, W. (2013). Important plants of northern Nimba County, Liberia: a guide to the most useful, rare or ecologically important species, with Mano names and uses. Forestry Institute, Oxford.

Marshall, H. S. (1951). Palisot de Beauvois's Flore d'Oware et de Benin, en Afrique. Kew Bull. 6 (1): 43 - 49.

McDade, L. A., Daniel, T. F. \& Kiel, C. A. (2008). Toward a comprehensive understanding of phylogenetic relationships among lineages of Acanthaceae s.l. (Lamiales). Amer. J. Bot. 95 (9): 1136 - 1152.

Moore, S. le M. (1880). Enumeratio Acanthacearum Herbarii Welwitschiani Angolensis. J. Bot. 18: 225 233.

(1930). Mr. John Gossweiler's plants from Angola and Portuguese Congo. Dicotyledones. Part. II. Gamopetalae. J. Bot. 68 (2): 3 - 175.

Nees von Esenbeck, C. G. (1847). Acanthaceae. In: A. L. P. P. de Candolle (ed.), Prodromus systematis naturalis regni vegetabilis 11: 46 - 519. Treuttel \& Würzt, Paris \& Strasbourg \& London.

Onana, J. M. \& Cheek, M. (2011). Red Data Book of the Flowering Plants of Cameroon. Royal Botanic Gardens, Kew.

Pakia, M. (2006). African traditional plant knowledge today: An ethnobotanical study of the Digo at the Kenya Coast, Beitr. Afrikaforschung 24: 1 - 217.

Poorter, L. (2004). Biodiversity of West African forests: an ecological atlas of woody plant species. CABI publishing, Wallingford.

POWO (2020). Plants of the World Online. Facilitated by the Royal Botanic Gardens, Kew. http:// www.plantsoftheworldonline.org/. [Accessed 23 Jan. 2020].

Prieu, C., Sauquet, H., Gouyon, P. H. \& Albert, B. (2017). More than sixty origins of pantoporate pollen in angiosperms. Amer. J. Bot. 104 (12): 1837 - 1845.

Protected Planet (2020). The World Data Base on Protected Areas. https://www.protectedplanet.net. [Accessed Jan. 2020].

QGIS Development Team (2020). QGIS Geographic Information System. Open Source Geospatial Foundation. Available from: https:/ /qgis.org. [Accessed Jan. 2020].

Robyns, W. (1943). Sympétales nouvelles de la région du Parc National Albert (Congo belge). Bull. Jard. Bot. État Bruxelles 17 (1): 65 - 107.

Romeiras, M. M., Figueira, R., Duarte, M.C., Beja, P. \& Darbyshire, I. (2014). Documenting biogeographi- 
cal patterns of African timber species using herbarium records: a conservation perspective based on native trees from Angola. PLoS ONE 9 (7): e103403.

Ron, T. (2013). Strategic plan: towards a transboundary protected area complex in the Mayombe forest ecosystems. http://www.iucn.org/library. [Accessed Nov. 2019].

Salzmann, U. \& Hoelzmann, P. (2005). The Dahomey Gap: an abrupt climatically induced rain forest fragmentation in West Africa during the late Holocene. The Holocene 15 (2): 190 - 199.

Shorthouse, D. P. (2010). SimpleMappr, an online tool to produce publication-quality point maps. http:// www.simplemappr.net. [Accessed Jan. - Dec. 2019].

Stapf, O. (1906). Appendix IV. List of the known plants of Liberia. In: H. Johnston, Liberia 2: 570 668. Hutchinson \& Co., London.

Stévart, T., Texier, N., Bidault, E., Phillipson, P. B. \& Lowry, P. P. (2016). Threatened Plant Species of Gabon. Missouri Botanical Garden, St. Louis. http:// tropicos.org/Project/Threatened_Plants_Gabon. [Accessed Feb. 2020].

Thiers, B. (continuously updated). Index Herbariorum: a global directory of public herbaria and associated staff. New York Botanical Garden's Virtual Herbarium. http:// sweetgum.nybg.org/ih/ [Accessed Feb. 2020].

Tripp, E. A. \& Manos, P. S. (2008). Is floral specialization an evolutionary dead-end? Pollination system transitions in Ruellia (Acanthaceae). Evolution 62 (7): 1712 - 1737.

, Daniel, T. F., Fatimah, S. \& McDade, L. A. (2013). Phylogenetic relationships within Ruellieae (Acanthaceae) and a revised classification. Int. J. Pl. Sci. 174 (1): 97 - 137.

Turrill, W. B. (1920). Diagnoses Africanae LXXIII. Bull. Misc. Inform., Kew 1: 23 - 29.

Turland, N. J., Wiersema, J. H., Barrie, F. R., Greuter, W., Hawksworth, D. L., Herendeen, P. S., Knapp, S.,
Kusber, W. H., Li, D. Z., Marhold, K. \& May, T. W. (2018). International Code of Nomenclature for algae, fungi, and plants (Shenzhen Code) adopted by the Nineteenth International Botanical Congress Shenzhen, China, July 2017. Regnum Veg. 159. Koeltz Botanical Books, Glasshütten.

Velayos, M., Cabezas, F., Barberá, P., Estrella, M. D. L., Aedo, C., Morales Valverde, R., Quintanar Sánchez, A., Velayos, G. \& Fero, M. (2013). Preliminary checklist of vascular plants of Bioko Island (Equatorial Guinea). Bot. Complutensis 37: 109 - 133.

Vollesen, K. (2004). A "new" Whitfieldia (Acanthaceae) from East Africa. Kew Bull. 59 (1): 123 - 127.

(2008). Whitfieldia. In: H. Beentje \& S. Ghazanfar (eds), Flora of Tropical East Africa. Acanthaceae (Part I): 266 - 270. Royal Botanic Gardens, Kew.

(2013). Whitfieldia. In: J. R. Timberlake \& E. S. Martins (eds), Flora Zambesiaca 8 (5): 173 - 175. Royal Botanic Gardens, Kew.

Walters, G., Dauby, G., Stevart, T., Dessein, S., Niangadouma, R. \& Lachenaud, O. (2011). Novitates Gabonenses 80. Additions and corrections to the flora of Gabon. Edinburgh J. Bot. 68 (3): $423-442$.

White, F. (1962). Forest flora of Northern Rhodesia. Oxford University Press, Oxford.

Wieringa, J. J. \& Mackinder, B. A. (2012). Novitates Gabonensis 79: Hymenostegia elegans and H. robusta spp. nov.(Leguminosae-Caesalpinioideae) from Gabon. Nord. J. Bot. 30 (2): 144 - 152.

\section{Publisher's Note}

Springer Nature remains neutral with regard to jurisdictional claims in published maps and institutional affiliations. 